\title{
THE QUALIFIED LEGAL COMPLIANCE COMMITTEE: USING THE ATTORNEY CONDUCT RULES TO RESTRUCTURE THE BOARD OF DIRECTORS
}

\author{
JILL E. FISCH $\dagger$ \\ CAROLINE M. GENTILE ††
}

\begin{abstract}
The Securities and Exchange Commission introduced a new corporate governance structure, the qualified legal compliance committee, as part of the professional standards of conduct for attorneys mandated by the Sarbanes-Oxley Act of 2002. QLCCs are consistent with the Commission's general approach to improving corporate governance through specialized committees of independent directors. This Article suggests, however, that assessing the benefits and costs of creating QLCCs may be more complex than is initially apparent. Importantly, QLCCs are unlikely to be effective in the absence of incentives for active director monitoring. This Article concludes by considering three ways of increasing these incentives.
\end{abstract}

Copyright (C) 2003 by Jill E. Fisch and Caroline M. Gentile.

$\dagger$ Alpin J. Cameron Professor of Law and Director, Center for Corporate, Securities \& Financial Law, Fordham University School of Law.

t† Associate Professor, Fordham University School of Law. We presented earlier drafts of this Article as part of the Fordham Law School Faculty Workshop Series and the University of San Diego Law School Faculty Workshop Series, and we received many helpful comments at each workshop. We also thank the Institute for Law and Economic Policy for providing a forum for presenting this Article at its annual conference on April 4, 2003, which was cosponsored by the Duke Law Journal. Finally, we are grateful for thoughtful suggestions from Bill Bratton, Roger Goebel, Abner Greene, Tom Lee, Peter Siegelman, and Ben Zipursky. 


\section{TABLE OF CONTENTS}

Introduction 518

I. Background to Rule 205 ..................................................................523

A. The Congressional Mandate: Section 307 and Gatekeeper Accountability..... 523

B. Commission Rulemaking: Rule 205 and the Creation of the QLCC 528

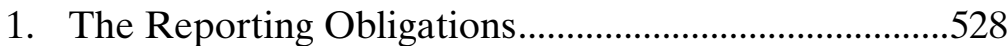

2. The Requirements of the QLCC ……….......................532

II. Problems with QLCCs..................................................................534

A. The Impact of QLCCs on Attorneys as Gatekeepers ........535

B. The Factors Influencing Decisions To Create QLCCs......539

1. The Benefits and Costs of QLCCs .................................539

2. The Role of Attorneys ………………………................546

C. Lessons from Audit Committees...........................................552

1. The Experience with Audit Committees .......................553

2. The Audit Committee Analogy …………......................555

3. The Effectiveness of Audit Committees.........................557

III. Creating Incentives for Director Activism ..................................566

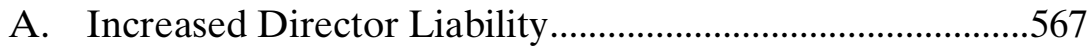

B. Changes To Director Compensation ....................................575

C. Alternative Director Selection Procedures...........................578

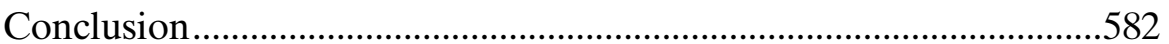

\section{INTRODUCTION}

The late 1990s was a golden age for corporate America-or so it seemed. Corporations reported ever-increasing earnings. Stock prices continually rose, leading market capitalization to an all time high. Everyone was happy. Investors delighted in the rapidly rising values of their portfolios, executives received staggering compensation, employees took comfort in the stability of their jobs and the steady growth of their retirement funds, and auditors, analysts, and attorneys collected larger and larger fees. Then, like a house of cards, it all came crashing down. Suddenly, the public learned that the reported profits were a sham and that executives had been engaged in massive fraud. Investors lost billions of dollars, employees lost their jobs and their retirement savings, and company after company collapsed. 
The crash in stock prices, together with reports of widespread corporate misconduct, led to demands for regulatory reform to prevent this debacle from happening again. Although the evidence indicates that corporate management at companies like Enron, Tyco, and Worldcom bore primary responsibility for the wrongdoing and the unprecedented losses, ${ }^{1}$ many commentators argue that gatekeepers-including accountants, analysts, and attorneys-were also responsible. ${ }^{2}$ These critics argue that conflicts of interest and a lack of regulatory accountability led gatekeepers to ignore problems as they developed, asserting that responsible gatekeeper behavior would have prevented, or at least limited, misconduct. ${ }^{3}$

Congress, apparently accepting this gatekeeper argument, enacted the Sarbanes-Oxley Act of 2002 (Sarbanes-Oxley). ${ }^{4}$ Notably, the primary focus of Sarbanes-Oxley is gatekeeper accountability. ${ }^{5}$ Although the central state law mechanism for monitoring corporate decisionmaking is the board of directors-and particularly the independent director-Sarbanes-Oxley did not impose federal

1. See, e.g., Barnaby J. Feder, Management Practice Enabled Huge Fraud, 2 Investigations Find, N.Y. TIMES, June 10, 2003, at C1 (describing findings of two reports, which concluded that the chief executive officer of Worldcom fostered fraud that was undertaken by other managers); William C. Powers, Jr. et al., Report of Investigation by the Special Investigative Committee of the Board of Directors of Enron Corp., 18-22 (Feb. 1, 2002), available at http://news.findlaw.com/ hdocs/docs/enron/sicreport/ (on file with the Duke Law Journal) (describing the role of Enron's management in the company's wrongdoing); Tyco Int'l Ltd., Form 8-K (Sept. 10, 2002), available at http://www.freeedgar.com (on file with the Duke Law Journal) (describing the improper and illegal conduct of Tyco's management and the related errors in the company's accounting disclosures).

2. Accountants, analysts, and attorneys provide professional services to corporations (and to investors). Most importantly, these professionals pledge their reputational capital, acquired over many years and many clients, to assure the accuracy, or at least the honesty, of the statements they either make or certify regarding the corporations.

3. See, e.g., John C. Coffee, Jr., Understanding Enron: "It's About the Gatekeepers, Stupid," 57 BUS. LAW. 1403, 1405 (2002) (attributing significant responsibility for the collapse of Enron to outside professional "gatekeepers" such as auditors and attorneys); R. William Ide, Post-Enron Corporate Governance Opportunities: Creating a Culture of Greater Board Collaboration and Oversight, 54 MERCER L. REV. 829, 841-45 (2003) (describing widespread blame of recent corporate failures and frauds on gatekeeper inadequacies).

4. Sarbanes-Oxley Act of 2002, Pub. L. No. 107-204, 116 Stat. 745 (codified in scattered sections of 11, 15, 18, 28, and 29 U.S.C.A. (West Supp. 2003)). Officially, this statute is entitled the "Public Company Accounting Reform and Investor Protection Act of 2002," and it is generally referred to as the Sarbanes-Oxley Act of 2002.

5. The provisions of the statute addressing the accountability of gatekeepers are described infra in Part II.A. 
standards for director liability. ${ }^{6}$ Similarly, despite a persistent strain of academic criticism charging that state corporate law is unduly lax in constraining management behavior, ${ }^{7}$ Sarbanes-Oxley did not implement federal limitations on management conduct. Instead, Congress sought, through Sarbanes-Oxley, to improve corporate decisionmaking indirectly by imposing new obligations-including standards of conduct, ${ }^{8}$ regulation of conflicts, ${ }^{9}$ and disclosure obligations $^{10}$ - on outside professionals who perform services for corporations, auditors, analysts, and attorneys. ${ }^{11}$

Specifically, with respect to attorneys, section 307 of SarbanesOxley instructs the Securities and Exchange Commission (Commission) to adopt minimum standards for attorney conduct, including a requirement that attorneys report evidence of misconduct "up the corporate ladder."

6. Cf. William L. Cary, Federalism and Corporate Law: Reflections upon Delaware, 83 YALE L.J. 663, 693-703 (1974) (advocating federal "minimum standards" for director conduct). The statute did formalize requirements for the audit committees of public companies that had previously been addressed by Commission rules and listing standards. See Sarbanes-Oxley Act of $2002 \S 301$, 15 U.S.C.A. $\S 78 \mathrm{j}-1$ (West Supp. 2003) (setting forth standards for audit committees).

7. See, e.g., Lucian A. Bebchuk, Federalism and the Corporation: The Desirable Limits on State Competition in Corporate Law, 105 HARV. L. REV. 1437 (1992) (identifying areas in which state corporate law is unlikely to produce adequate constraints on management self-dealing); Lucian A. Bebchuk \& Allen Ferrell, Federalism and Corporate Law: The Race to Protect Managers from Takeovers, 99 CoLUM. L. REV. 1168, 1172-73 (1999) (demonstrating shortcomings of state law with respect to takeover regulation); Cary, supra note 6, at 696-705 (describing Delaware corporate law as favoring management interests over shareholder interests and recommending adoption of minimum federal standards).

8. Congress charged the Public Company Accounting Oversight Board with establishing auditing and related attestation standards, quality control standards, and ethical standards to be used by public accounting firms in the preparation and issuance of audit reports. $\S 103,15$ U.S.C.A. $\S 7213$. With respect to attorneys, Congress directed the Commission to issue rules setting forth minimum standards of conduct. § 307, 15 U.S.C.A. § 7245.

9. For example, Congress amended section 10A of the Securities Exchange Act of 1934 to make it unlawful for a registered public accounting firm to perform an audit for an issuer if the issuer's chief executive officer, controller, chief financial officer, or chief accounting officer was employed by the accounting firm and participated in an audit of the issuer within the preceding year. § 206, 15 U.S.C.A. § 78j-1. Congress also directed the Commission to adopt rules to address analyst conflicts of interest in connection with investment banking operations. §501, 15 U.S.C.A. $\$ 78 o-6$.

10. See, e.g., § 204, 15 U.S.C.A. $78 \mathrm{j}-1$ (requiring auditors to report to the issuer's audit committee all critical accounting policies and practices, all alternative treatments of financial information that have been discussed with members of management, and all material written communications between the issuer and management).

11. These provisions of the statute are described in greater detail infra in Part II.A. 
The Commission responded to section 307 by promulgating Rule $205,{ }^{12}$ which requires attorneys representing public issuers of securities to report evidence of misconduct to the chief legal officer of the issuer, and, in some cases, to the audit committee and/or the board of directors. ${ }^{13}$ Importantly, however, the Commission did not stop there. Rule 205 also provides an alternative mechanism by which attorneys can fulfill their reporting obligations: the qualified legal compliance committee (QLCC). ${ }^{14}$ If an issuer creates a QLCC in accordance with Rule 205, attorneys may fully satisfy their reporting obligations under the rule simply by reporting evidence of misconduct to the QLCC. ${ }^{15}$

Although the Commission apparently believes that QLCCsindependent board committees empowered to act independentlyare the best means of identifying, investigating, and responding to reports of misconduct, the introduction of this alternative mechanism to accomplish these tasks creates several problems. First, the introduction of the QLCC represents a departure from congressional efforts to improve corporate decisionmaking by increasing the responsibilities of gatekeepers. While we do not defend the emphasis on gatekeepers in Sarbanes-Oxley as the most appropriate method for addressing the types of misconduct identified in recent disclosures, ${ }^{16}$ we note that questions concerning the efficacy of the gatekeeper model do not mitigate the problems inherent in frustrating the structure of the statutory scheme. ${ }^{17}$

Second, the Commission has failed to consider the costs to issuers of creating QLCCs-costs that may be substantial. At the same time, the Commission may have overstated the purported benefits that QLCCs confer on issuers. Moreover, the creation of the QLCC provides distinct benefits to the attorneys representing an

12. Standards of Professional Conduct for Attorneys Appearing and Practicing Before the Commission in the Representation of an Issuer, 17 C.F.R. $\$ 205$ (2003).

13. Id. $\$ 205.3$.

14. Id. $§ 205.3(\mathrm{c})$. The requirements for a properly created QLCC are described infra in Part I.B.2.

15. Id. $\S 205.3(\mathrm{c})(1)$.

16. Indeed one of us has criticized congressional efforts to impose gatekeeping obligations on attorneys. See Jill E. Fisch \& Kenneth M. Rosen, Is there a Role for Lawyers in Preventing Future Enrons?, 48 VILL. L. REV. 1097, 1130-31 (2003) (arguing that an attorney's role is inconsistent with the independence required of an effective gatekeeper).

17. Given the broad scope of Sarbanes-Oxley and the traditional deference given to the Commission in performing its rulemaking function, we do not go so far as to argue that Rule 205 is subject to a challenge of invalidity. 
issuer. When an attorney reports evidence of misconduct to a QLCC rather than to an officer or the board of directors, the attorney's reporting obligations and exposure to liability are both reduced. Due to the importance of attorneys as mediating agents in advising their clients about the decision to create a QLCC, these benefits present a risk that issuers will face "backdoor" pressure to create QLCCs stemming from the market for legal services.

Third, although QLCCs reflect the Commission's vision of the best means of regulating corporate conduct - through an emphasis on board structure, including the increasing use of specialized board committees comprised of independent directors-we question whether this model of the "specialist director" can address fundamental problems of director passivity and effectuate a meaningful difference in the behavior of boards of directors. ${ }^{18}$ To consider the potential effectiveness of QLCCs, we look to the role and the impact of audit committees, which are, we argue, analogous to QLCCs in important ways. ${ }^{19}$ In light of the ambiguous evidence on audit committee effectiveness, we conclude by considering alternative mechanisms for improving director incentives to identify and respond to evidence of corporate misconduct.

This Article proceeds as follows. Part I describes Rule 205, beginning with the political context in which Congress enacted Sarbanes-Oxley and the history of the Commission's efforts to regulate attorney conduct and then turning to the provisions of Rule 205. Part II considers the potential benefits and costs to the issuer of creating a QLCC, as well as the incentives facing attorneys in advising an issuer to create a QLCC. Because QLCCs are, as yet, an untested tool, we look to the experience with audit committees for guidance in predicting the likely success of QLCCs in addressing misconduct. Finally, Part III identifies alternative mechanisms to increase director accountability as a means of addressing the principal limitation of QLCCs - the failure to provide sufficient incentives to overcome director passivity. Specifically, we consider greater director liability exposure, changes to director compensation, and alternative processes for selecting directors. Although each of these methods is

18. The Commission's emphasis on the importance of independent and expert directors serving as members of audit committees is described infra in Part II.C.1.

19. The Commission's initiatives with respect to audit committees are described infra in Part II.C.1. 
imperfect, collectively they illustrate the limitations of the Commission's current regulatory approach. ${ }^{20}$

\section{BACKGROUND TO RULE 205}

In section 307 of Sarbanes-Oxley, Congress directed the Commission to adopt minimum standards of attorney conduct, including a requirement that attorneys report evidence of misconduct up the corporate ladder. ${ }^{21}$ Responding to this directive, the Commission adopted Rule 205, which sets forth minimum standards of professional conduct for attorneys appearing before the Commission, ${ }^{22}$ including a requirement that attorneys representing an issuer report evidence of misconduct up the ladder. ${ }^{23}$ The Commission, however, went further, introducing the QLCC as an alternative mechanism for reporting, as well as investigating and responding to, misconduct. ${ }^{24}$

To understand the significance of Rule 205 and the QLCC alternative, it is important to consider the background to the rule. Accordingly, in Section A, we summarize the political context in which Congress enacted Sarbanes-Oxley and the history of the Commission's efforts to regulate attorney conduct. In Section B, we focus directly on Rule 205, concentrating on the rule's reporting obligations and the requirements for creating a QLCC.

\section{A. The Congressional Mandate: Section 307 and Gatekeeper Accountability}

In the wake of disclosures of extensive wrongdoing and unprecedented losses to investors at Enron, Tyco, Worldcom, and other corporations, Congress undertook the task of adopting federal legislation designed to reduce the risk of future

20. Importantly, the analysis contained in this Article is confined to evaluating QLCCs from a corporate governance perspective. The Article does not include an evaluation of whether it is appropriate for the Commission to promulgate standards of attorney conduct or an evaluation of the Commission's recently promulgated standards. For an analysis of these questions, see Fisch \& Rosen, supra note 16, at 1097.

21. Sarbanes-Oxley Act of $2002 \S 307,15$ U.S.C.A. $§ 7245$ (West Supp. 2003).

22. 17 C.F.R. $\$ 205$.

23. Id. $\$ 205.3(\mathrm{~b})$.

24. Id. $\$ 205.3(\mathrm{c})$. 
misconduct. ${ }^{25}$ Congress focused its efforts primarily on advisorsaccountants, analysts, and attorneys who provide professional services to corporations-rather than on the executives who run the corporations (and who bore primary responsibility for the wrongdoing) or the directors who oversee the decisions made by the executives (and who acquiesced in the wrongdoing). The rationale for this approach appears to be a view that gatekeepers were largely to blame for the failures in corporate governance. Under this view, conflicts of interest and the absence of regulatory accountability permitted gatekeepers to ignore critical problems while earning enormous fees from their clients. ${ }^{26}$ Consequently, the reforms of Sarbanes-Oxley are principally directed toward improving the incentives and responsibilities of gatekeepersespecially accountants. ${ }^{27}$

As originally introduced in Congress, Sarbanes-Oxley did not contain a provision addressing standards of attorney conduct. ${ }^{28} \mathrm{~A}$ letter written by Professor Richard Painter, together with forty other law professors, seems to have been a key factor triggering the inclusion of attorney conduct within the reforms of Sarbanes-Oxley. The letter urged the Commission to compel securities lawyers to report evidence of wrongdoing up the ladder within each issuer they represent. ${ }^{29}$ Professor Painter suggested that the Commission both promulgate a rule clearly requiring disclosure to the issuer's directors

25. See Greg Hitt, Bush Signs Sweeping Legislation Aimed at Curbing Corporate Fraud, WALl ST. J., July 31, 2002, at A4 (describing reform legislation as responsive to reported scandals at Enron, Global Crossing, Tyco, Qwest Communications, and WorldCom, among others).

26. This emphasis on gatekeepers may not be appropriate. See, e.g., Fisch \& Rosen, supra note 16, at 1130-31 (questioning whether attorneys can function as effective gatekeepers).

27. The second title of Sarbanes-Oxley implements a number of reforms that are designed to enhance the independence of accountants who audit financial statements. Sarbanes-Oxley Act of 2002, $\S \S 201-209,15$ U.S.C.A. $\S \S 7231-7234$ (West Supp. 2003) (amending section 10A of the Securities Exchange Act of 1934, 15 U.S.C. $\$ 78 j-1$ (2000)). Analysts are also the subject of enhanced scrutiny and regulation. § 501, 15 U.S.C.A. § 78o-6. These reforms and regulations are described infra in Part II.A.

28. See, e.g., Corporate and Auditing Accountability, Responsibility, and Transparency Act of 2002, H.R. 3763, 107th Cong. (2002) (containing no provisions addressing attorney conduct); Public Company Accounting Reform and Investor Act of 2002, Report of the Senate Committee of Banking, Housing \& Urban Affairs, S. Rep. No. 107-205, 107th Cong., 2d. Sess. (2002) (containing no provisions addressing attorney conduct).

29. Letter from Richard W. Painter, Professor of Law at University of Illinois College of Law, to Harvey L. Pitt, Chairman, SEC (March 7, 2002), available at http://www.abanet.org/ buslaw/corporateresponsibility/pitt.pdf (on file with the Duke Law Journal). 
and enforce the rule vigorously. ${ }^{30}$ The Commission, through General Counsel David Becker, responded to Professor Painter's letter by referencing the lengthy history and controversy surrounding the appropriate role of the Commission in regulating attorney conduct. ${ }^{31}$

The history dates to the 1970s. In National Student Marketing, ${ }^{32}$ the Commission took the position that attorneys who knew that their client had entered into a merger by making materially misleading disclosures had an affirmative duty to prevent the merger. ${ }^{33}$ In particular, the Commission stated that if the client refused to follow the attorneys' recommendation to make corrective disclosure, "the attorneys should have withdrawn from the representation and informed the shareholders or the Commission." ${ }^{\prime 34}$ The Commission later confirmed its position. In 1981, the Commission, in In re Carter (Carter \& Johnson) ${ }^{35}$ explained that an attorney who is aware of a client's continuing and substantial violations of the securities laws is required to "take[] prompt steps to end the client's noncompliance."”6 The Commission then stated that an attorney's obligations could extend to reporting evidence of misconduct up the corporate ladder to the board of directors. ${ }^{37}$

At the same time, the Commission considered direct rulemaking that would require attorneys to report evidence of misconduct up the ladder. In November 1978, the Institute for Public Interest Representation at Georgetown University Law Center asked the Commission to amend Rule 2(e) "to require an attorney who discovers that his client has been guilty of a material misstatement or omission to bring the facts and legal implications to the attention of management. ${ }^{\prime 3}$ The Commission responded by publishing the

30. Id.

31. Letter from David Becker, General Counsel, SEC, to Richard W. Painter, Professor of Law, University of Illinois College of Law (Mar. 28, 2002) (on file with the Duke Law Journal).

32. SEC v. Nat. Student Mktg., 457 F. Supp. 682 (D.D.C. 1978).

33. Id. at 700 .

34. Id.

35. In re Carter \& Johnson, [1981 Transfer Binder] Fed. Sec. L. Rep. (CCH) II 82,847, at 84,145 (Feb. 28, 1981).

36. Id. at 84,172 .

37. Id.

38. Robert J. Wilczek, Corporate Confidentiality: Problems and Dilemmas of Corporate Counsel, 7 DEL. J. CORP. L. 221, 228 (1983); see also H. Lowell Brown, The Dilemma of Corporate Counsel Faced with Client Misconduct: Disclosure of Client Confidences or Constructive Discharge, 44 BUFF. L. REV. 777, 805 n.97 (1996) (describing the proposal). 
proposal for public comment. ${ }^{39}$ After the decision in Carter \& Johnson, the Commission also took the unusual step of publishing a second request for comment, specifically focusing on the standard of attorney conduct articulated by the decision. ${ }^{40}$ These efforts were highly controversial. The private bar charged the Commission both with acting beyond the scope of its authority to become a putative bar association and with improperly interfering with an attorney's obligation of client confidentiality. ${ }^{41}$

The Commission subsequently retreated from its attempt to implement standards of attorney conduct through litigation and rulemaking. ${ }^{42}$ In a 1982 speech by Commission General Counsel Edward Greene, the Commission stated that, henceforth, it would adhere to a policy of restricting disciplinary efforts against attorneys until there had been a judicial finding that the attorney had violated the federal securities laws. ${ }^{43}$ The Commission reaffirmed this position in a 1988 release, observing that it would continue to adhere to its position of using Rule 102(e) proceedings against attorneys "only where the attorney's conduct has already provided the basis for a judicial or administrative order finding a securities violation in a nonrule $[102(\mathrm{e})]$ proceeding. ${ }^{, 44}$

The Commission maintained this basic position over the course of the next fifteen years, although actions against attorneys, from time to time, seemed to indicate that the Commission believed that

39. Request for Comments on Petition Concerning Disclosure of Relationships Between Attorneys and Registrants, Exchange Act Release No. 16,045, [1979 Transfer Binder] Fed. Sec.

L. Rep. (CCH) II 82,144, at 82,049 (July 25, 1979); Brown, supra note 38, at 805 n.98.

40. Securities and Exchange Commission, Request for Comments on Standard of Conduct Constituting Unethical or Improper Professional Practice Before the Commission, 46 Fed. Reg. 48,233 (Oct. 1, 1981).

41. See Wilczek, supra note 38, at 230-31 (noting "objections . . to the implicit assertion that the Commission has the authority to impose substantive standards ... [and that] it is contrary to the attorney-client privilege and to the ethical obligations to maintain client confidences").

42. See Denial of Petition for Rule-Making Concerning Disclosure of Relationships Between Attorneys and Registrants, 45 Fed. Reg. 30,454 (May 8, 1980) (codified at 17 C.F.R. pt. 240 (2003)) (describing the Commission's withdrawal of the proposed rule); Susan P. Koniak, When the Hurlyburly's Done: The Bar's Struggle with the SEC, 103 COLUM. L. REV. 1236, 1260 (2003) (describing the way the Commission "let the proposed Carter \& Johnson rule die a quiet death").

43. Edward F. Greene, Remarks to the New York County Lawyer's Association, [1982 Transfer Binder] Fed. Sec. L. Rep. (CCH) II 83,089, at 84,802 (Jan. 18, 1982).

44. Disciplinary Proceedings Involving Professionals Appearing or Practicing Before the Commission, Exchange Act Release No. 25,893, 53 Fed. Reg. 26,427 (July 13, 1988) (codified at 17 C.F.R. pt. 201.102(e)). 
securities lawyers have an affirmative obligation to address client misconduct. For example, in In re Gutfreund, ${ }^{45}$ the Commission refrained from naming the chief legal officer as a respondent in its section 21(a) report despite the fact that he had been apprised of criminal misconduct by another executive. ${ }^{46}$ Nonetheless, the Commission stated that legal and compliance officers who learn of misconduct are "obligated to take affirmative steps to ensure that appropriate action is taken to address the misconduct," including "disclosure of the matter to the entity's board of directors, resignation from the firm, or disclosure to regulatory authorities." ${ }^{47}$ The Commission, however, neither articulated clear standards of conduct nor adopted a more vigorous enforcement policy. ${ }^{48}$

In responding to Professor Painter's letter, General Counsel Becker referenced this history and stated that the Commission had, since Carter \& Johnson, declined to use Rule 102(e) as a mechanism for enforcing standards of attorney conduct. ${ }^{49}$ General Counsel Becker then stated that reconsideration of the Commission's position would more appropriately be undertaken in the context of congressional action. ${ }^{50}$

The Commission's response subsequently came to the attention of Senator John Edwards. In June 2002, just weeks before the adoption of Sarbanes-Oxley, ${ }^{51}$ Senator Edwards wrote Commission Chairman Harvey Pitt in reference to Professor Painter's letter and the Commission's response. ${ }^{52}$ Senator Edwards stated that, in his view, "a lawyer with knowledge of managers' serious, material, and unremedied violations of federal securities law should have an obligation to inform the board of those violations. ${ }^{, 53}$ Senator Edwards went on to assert that the obligation should be imposed as a matter of federal law or regulation and that "[r]ecognition and enforcement of 1992).

45. In re Gutfreund, [1992 Transfer Binder] Fed. Sec. L. Rep. (CCH) II 85,067 (Dec. 3,

46. Id. at $83,608-09$.

47. Id. at 83,609 .

48. E.g., id.; In re Kern, [1991 Transfer Binder] Fed. Sec. L. Rep. (CCH) II 84,815, at 82,004 (June 21, 1991).

49. Letter from David Becker to Richard W. Painter, supra note 31.

50. Id.

51. President Bush signed Sarbanes-Oxley into law on July 30, 2002. Hitt, supra note 25.

52. Letter from John Edwards, United States Senator from North Carolina, to Harvey Pitt, SEC Chairman (June 18, 2002), reprinted in 148 CONG. REC. S5,652, S5,652-53 (daily ed. June 18, 2002).

53. Id., reprinted in 148 CONG. REC. S5,652, S5,653 (daily ed. June 18, 2002). 
this important but limited obligation could prevent substantial harms to shareholders and the public., ${ }^{54}$ Senator Edwards then asked Chairman Pitt whether the Commission intended to enforce this minimum standard of conduct for securities lawyers and, if not, sought Chairman Pitt's assistance in drafting appropriate legislation to create such an obligation. ${ }^{55}$

On July 10, 2002, less than a month after his letter to Chairman Pitt, Senator Edwards introduced the Edwards Amendment to Senate Resolution 2673, which, with essentially no debate, was adopted and codified as section 307 of Sarbanes-Oxley. ${ }^{56}$ The statute directed the Commission, within 180 days of its enactment, to adopt rules requiring attorneys (1) to report evidence of issuer misconduct up the corporate ladder to the issuer's chief legal officer or chief executive officer, and (2) in the absence of an appropriate response, to report the misconduct further up the ladder to the issuer's audit committee, another independent board committee, or the full board of directors. ${ }^{57}$

In response to this statutory mandate, on November 21, 2002, the Commission published for comment proposed Rule 205. ${ }^{58}$ The proposed rule received 167 letters of comment. ${ }^{59}$ On January 23, 2003, the Commission adopted Rule $205 .^{60}$

\section{B. Commission Rulemaking: Rule 205 and the Creation of the QLCC}

1. The Reporting Obligations. Consistent with the mandate of section 307, Rule 205 requires any attorney ${ }^{61}$ who becomes aware of

54. Id.

55. $I d$.

56. See 148 CONG. REC. S6,551 (daily ed. July 10, 2002) (statement of Sen. Edwards) (introducing the Edwards Amendment 4187 to Senate Resolution 2673).

57. Sarbanes-Oxley Act of 2002 § 307, 15 U.S.C.A. $\$ 7245$ (West Supp. 2003).

58. Implementation of Standards of Professional Conduct for Attorneys, Exchange Act Release No. 47,276, [2002-2003 Transfer Binder] Fed. Sec. L. Rep. (CCH) II 86,802, at 86,513 (Nov. 21, 2002) [hereinafter Proposing Release].

59. Implementation of Standards of Professional Conduct for Attorneys, Exchange Act Release No. 47,276, [2002-2003 Transfer Binder] Fed. Sec. L. Rep. (CCH) II 86,823, at 87,070 (Jan. 29, 2003) [hereinafter Adopting Release].

60. Id. at 87,069. Although the Adopting Release is dated January 29, 2003, the Commission adopted the Rule on January 23, 2003. Elizabeth S. Stong, The SEC Adopts a Rule on Attorney Conduct, Metropolitan Corp. Couns., Mar. 2003, at 9.

61. The rule applies to attorneys "appearing and practicing before the Commission," which is defined in Rule 205.2(a) to include attorneys transacting any business before the Commission, representing an issuer in a Commission proceeding or investigation, providing advice in respect 
evidence of a material violation of the securities laws, a material breach of fiduciary duty, or a similar material violation, ${ }^{62}$ to report the matter to the issuer's chief legal officer..$^{63}$ If, following this first step, the reporting attorney reasonably believes that neither the chief legal officer nor the chief executive officer has provided an appropriate response ${ }^{64}$ the attorney must report the matter to others within the issuer: the audit committee, another independent committee, or the entire board of directors. ${ }^{65}$

of the securities laws, or advising whether or not information or materials must be filed with the Commission. 17 C.F.R. § 205.2(a) (2003).

62. "Material violation" is defined as "a material violation of an applicable United States federal or state securities law, a material breach of a fiduciary duty arising under United States federal or state law, or a similar material violation of any United States federal or state law." Id. $\S 205.2(i)$. A "breach of fiduciary duty" refers to "any breach of a fiduciary of similar duty [owed to an issuer] under an applicable federal or state statute or at common law, including but not limited to misfeasance, nonfeasance, abdication of duty, abuse of trust, and approval of unlawful transactions." Id. § 205.2(d).

63. The attorney may also report the matter to both the chief legal officer and the chief executive officer. $I d$. $\S 205.3(\mathrm{~b})(1)$.

64. The rule defines an "appropriate response" as a response after which the reporting attorney reasonably believes: (1) "that no material violation [or material breach] has occurred, is on going, or is about to occur; that the issuer has, as necessary, adopted appropriate remedial measures"; or that the issuer has "retained or directed an attorney to review the reported evidence"; and (2) that the issuer either has "substantially implemented any remedial recommendations made by [the investigating] attorney" or has been advised by the investigating attorney that the attorney may assert a colorable defense on behalf of the issuer in any investigation or proceeding related to the reported evidence. Id. $\$ 205.2(\mathrm{~b})$. In addition, the rule defines "reasonably believes" to mean "that the attorney believes the matter in question and that the circumstances are such that the belief is not unreasonable." Id. § $205.2(\mathrm{~m})$.

65. Id. $\S 205.3(\mathrm{~b})(3)$. For purposes of the rule, "independent" directors are those directors who are not employed, either directly or indirectly, by the issuer, and an "independent" committee is a committee comprised solely of independent directors. $I d$. $\S 205.2(\mathrm{k})(1)$. The Adopting Release, however, states that "the Commission anticipates that these provisions [relating to the independence of directors] will be amended to conform to the final rules defining who is an 'independent' director under Section 301 of the [Sarbanes-Oxley] Act, upon adoption of those rules." Adopting Release, supra note 59, at 87,083. Section 301 requires the Commission to direct, by rule, the national securities exchanges and associations to prohibit the listing of any security of an issuer that is not in compliance with specified requirements relating to the independence, authority, responsibilities, functioning, and funding of expenses of audit committees. Sarbanes-Oxley Act of $2002 \S 301,15$ U.S.C.A. § 78j(1) (West Supp. 2003). The Commission adopted these rules on April 25, 2003. Standards Relating To Listed Company Audit Committees, Exchange Act Release No. 47,654, [2003 Transfer Binder] Fed. Sec. L. Rep. $(\mathrm{CCH})$ II 86,902, at 87,402 (Apr. 9, 2003) [hereinafter Listed Company Audit Committee Release]. Under these rules, which amend section 10A of the Securities Exchange Act of 1934, a member of an audit committee is not considered independent if he or she accepts any advisory, consulting, or other compensatory fee from the issuer, other than in his or her capacity as a member of the board of directors, or is affiliated with the issuer or any of its subsidiaries. $\S \S$ 201-209, 15 U.S.C.A. $\S \S 7231-7234$ (amending section 10A of the Securities Exchange Act of 1934, 15 U.S.C. $\$ 78 \mathrm{j}-1(2000))$. 
Rule 205 also requires the chief legal officer, upon receipt of a report of a possible material violation or material breach, to conduct a reasonable inquiry to determine whether or not the reported violation or breach has occurred, is occurring, or is about to occur. ${ }^{66}$ In the event the officer concludes that a material violation or a material breach has occurred, is occurring, or is about to occur, the rule requires that the officer take all reasonable steps to cause the issuer to adopt an appropriate response and to advise the reporting attorney of the officer's actions. ${ }^{67}$

These reporting-up requirements do not, however, apply in all circumstances. Rule 205 departs from the reporting structure established by section 307 by creating a limited exception to the reporting obligations in the case of an issuer that has created a QLCC. The QLCC is designed to serve as an alternative mechanism for receiving reports of misconduct and for investigating and responding to the allegations contained in those reports. ${ }^{68}$ If an issuer has established a QLCC, then, rather than reporting evidence of a material violation or a material breach to the issuer's chief legal officer, an attorney may simply report the matter to the QLCC. ${ }^{69}$ Similarly, rather than conducting an inquiry to determine whether or not a reported violation or breach has occurred, is occurring, or is about to occur, the chief legal officer may refer the matter to the QLCC. $^{70}$ Importantly, upon reporting a matter to the QLCC, a reporting attorney is relieved of all further obligations under the rule, ${ }^{71}$ and, upon referring a report to a QLCC, the chief legal officer is similarly relieved of further obligations under the rule. ${ }^{72}$

As yet, the QLCC has received little attention from commentators. Those comments provided to the Commission in response to the Proposing Release focused on minor components of the QLCC's operational structure. As the Commission reported in the Adopting Release, "[c]ommenters generally approved of the

\footnotetext{
66. 17 C.F.R. $§ 205.3(b)(2)$.

67. Id.

68. Adopting Release, supra note 59, at 87,082, 87,089.

69. 17 C.F.R. $\$ 205.3(\mathrm{c})(1)$.

70. $\quad I d . \S 205.3(\mathrm{c})(2)$.

71. Id. § 205.3(c)(1).

72. Id. § 205.3(c)(2); see Adopting Release, supra note 59, at 87,089 (“[T]he QLCC . . would be responsible for carrying out the steps required by Section 307 of the [Sarbanes-Oxley]
} Act."). 
QLCC in concept, although several proposed changes in how it would work." ${ }^{73}$

In contrast to the QLCC, which commentators largely accepted without objection, commentators strongly criticized the Commission's efforts to require reporting attorneys to make "noisy withdrawals." "74 As originally proposed, Rule 205 would have required an attorney who reports evidence of a material violation or a material breach to the chief legal officer to make, as a second step, a noisy withdrawal if the attorney

does not receive an appropriate response, or has not received a response in a reasonable time, to his or her report, and the attorney reasonably believes that a material violation is ongoing or is about to occur and is likely to result in substantial injury to the financial interest or property of the issuer or of investors.

To make a noisy withdrawal, an attorney must both withdraw from representing an issuer and notify the Commission of the withdrawal. ${ }^{76}$

73. Adopting Release, supra note 59, at 87,089.

74. Implementation of Standards of Professional Conduct for Attorneys, Exchange Act Release No. 47,282, [2002-2003 Transfer Binder] Fed. Sec. L. Rep. (CCH) It 86,824, at 87,11213 (Jan. 29, 2003) [hereinafter Second Proposing Release].

Commentators also criticized the Commission's efforts to impose record-keeping obligations on reporting attorneys and chief legal officers. Adopting Release, supra note 59, at 87,085-86. In the Proposing Release, the Commission sought to require attorneys to create contemporaneous records concerning their reports of misconduct and the responses to the reports. Proposing Release, supra note 58, at 86,535-36. The Commission also sought to require chief legal officers to document any inquiry conducted in response to a report of misconduct. Id. at 86,536-37. Those commenting on the Proposing Release criticized these requirements on the grounds that the obligations "could be an impediment to open and candid discussions between attorneys and their issuer clients," that the obligations had "the potential to create a conflict of interest between the lawyer and his or her client," and that the obligations "might increase the issuer's vulnerability in litigation." Adopting Release, supra note 59, at 87,085. In light of these comments, the Commission concluded that "[a]t least at the present time, the potential harms from mandating documentation may not justify the potential benefits" and refrained from including the record-keeping obligations in Rule 205. Id.

75. Proposing Release, supra note 58, at 86,541. Importantly, the requirement that the attorney make a noisy withdrawal is not applicable in situations in which the attorney has reported the evidence to a QLCC. See id. (stating that the noisy withdrawal requirement only applies to "an attorney who has reported evidence of a material violation under paragraph 3(b) of [Rule 205] rather than paragraph 3(c)").

76. The notice to the Commission was to indicate that the withdrawal was based on professional considerations and to disaffirm any document that the attorney reasonably believed to be materially false or misleading. 
The Commission described the noisy withdrawal provision as generating widespread objections. ${ }^{77}$ The Commission explained that "[s]ome commenters objected to the proposal because they are of the view that the Commission does not have the statutory authority to require "noisy withdrawal,", ${ }^{78}$ while others were "concerned that the provision would conflict with longstanding requirements under state ethics laws and therefore would infringe on the jurisdiction of state ethics-setting bodies." "79 "One commentator argued that such a provision would subject attorneys to conflicting liability claims, whether or not they complied with the rule," commentators believed that the rule would not further the Commission's goals because it would cause clients to exclude attorneys from meetings where information was exchanged that could lead an attorney to believe a material violation had been committed." ${ }^{81}$

In response to these criticisms, the Commission did not include a noisy withdrawal requirement as part of Rule $205 .{ }^{82}$ Instead, it deferred action on this proposal, extending the comment period until April 7, 2003..$^{83}$ At the same time, the Commission issued a new release soliciting comments on both its original proposal and an alternative proposal. ${ }^{84}$ The alternative proposal would require attorneys to withdraw from the representation of an issuer in a narrower set of circumstances. It would also require the issuer, rather than the attorney, to report the withdrawal to the Commission. ${ }^{85}$

2. The Requirements of the $Q L C C$. The QLCC provides an alternative mechanism for attorneys to report evidence of misconduct as well as for issuers to investigate and respond to allegations of

77. Second Proposing Release, supra note 74, at 87,112.

78. Id.

79. Id. at 87,113 .

80. Id.

81. $I d$.

82. Adopting Release, supra note 59, at 87,070.

83. Id.; Second Proposing Release, supra note 74 , at 87,113 .

84. Second Proposing Release, supra note 74, at 87,111. As in the case of the initial proposal, the noisy withdrawal requirement of the alternative proposal is not applicable in situations in which the attorney has reported the evidence to a QLCC. Id. at 87,115.

85. At the time this Article was published, the proposals concerning noisy withdrawal were still pending. 
misconduct. ${ }^{86}$ Rule 205.2(k) imposes precise requirements concerning the composition of the committee, the authority it must possess, and the procedures that it must follow in its operations. ${ }^{87}$

The QLCC must be duly created by the board of directors, with authority to act in accordance with the requirements of Rule $205^{88}$ The issuer may designate its audit committee or another existing committee to serve as the QLCC, so long as the composition of the committee satisfies the requirements of the rule. ${ }^{89}$ In any event, the committee must be comprised of at least one member of the issuer's audit committee and at least two other independent directors. ${ }^{90}$

The issuer's board must delegate specific authority and responsibility to the QLCC. ${ }^{91}$ In particular, Rule 205.2(k)(3) provides that the QLCC must have the authority and the responsibility to inform the chief legal officer and the chief executive officer of a report of evidence of a material violation or a material breach ${ }^{92}$ and to determine whether an investigation regarding a report is necessary. ${ }^{93}$ In the event the QLCC determines that an investigation is necessary, the committee must have the authority and the responsibility to inform the audit committee or the entire board of directors, ${ }^{94}$ to initiate an investigation, ${ }^{95}$ and to retain any additional expert personnel deemed necessary. ${ }^{96}$ Upon the conclusion of the investigation, the QLCC must have the authority and the responsibility to recommend that the issuer implement an appropriate response to the misconduct ${ }^{97}$ and to inform the chief legal officer, the chief executive officer, and the entire board of directors of the results

86. Standards of Professional Conduct for Attorneys Appearing and Practicing Before the Commission in the Representation of an Issuer, 17 C.F.R. $\$ 205.3$ (c) (2003).

87. Id. $\$ 205.2(\mathrm{k})$. Rule 205.3(c) also specifically requires that the issuer must have formed the committee prior to receipt of a report of a material violation or a material breach from an attorney or prior to a referral of a report from the chief legal officer. $I d$. $\S 205.3$ (c)(1).

88. Id. $\$ 205.2(\mathrm{k})(3)$.

89. Id. $§ 205.2(\mathrm{k})$.

90. Id. $\$ 205.2(\mathrm{k})(1)$.

91. Id. $\S 205.2(\mathrm{k})(3)$.

92. Id. $\S 205.2(\mathrm{k})(3)(\mathrm{i})$.

93. $I d . \S 205.2(\mathrm{k})(3)(\mathrm{ii})$.

94. Id. $\S 205.2(\mathrm{k})(3)(\mathrm{ii})(\mathrm{A})$.

95. $I d . \S 205.2(\mathrm{k})(3)(\mathrm{ii})(\mathrm{B})$.

96. Id. $\$ 205.2(\mathrm{k})(3)(\mathrm{ii})(\mathrm{C})$.

97. $I d . \S 205.2(\mathrm{k})(3)(\mathrm{iii})(\mathrm{A})$. 
of the inquiry and of the appropriate remedial measures to be adopted by the issuer. ${ }^{98}$

Rule 205.2(k) also specifies the manner in which a QLCC is to operate. The QLCC is required to adopt "written procedures for the confidential receipt, retention, and consideration of any report" of a material violation or a material breach. ${ }^{99}$ Decisions of the QLCC are to be made by majority vote. ${ }^{100}$ Finally, the QLCC must be specifically authorized to take "appropriate action" in the event the issuer fails in any "material respect" to implement its recommendations. ${ }^{101}$ In particular, the QLCC must have the authority to notify the Commission of the issuer's failure to implement its recommendations. ${ }^{102}$

\section{PRoblems WITH QLCCS}

Introducing the QLCC in Rule 205 as an alternative mechanism for reporting, investigating, and responding to misconduct not only reflects a departure from the structure of section 307, it creates several problems. We begin by examining the way the introduction of the QLCC shifts the focus of reform efforts from attorneys as gatekeepers to the structure and independence of boards of directors. We then consider the expected benefits and costs of QLCCs and, relatedly, the role of attorneys as mediating agents in an issuer's decision whether or not to create a QLCC. Finally, to assist in predicting the potential value of QLCCs, we review the history and the effect of the Commission's previous efforts to limit corporate misconduct through the use of audit committees-committees that are in many ways similar to QLCCs.

98. Id. § 205.2(k)(3)(iii)(B). The requirement that the QLCC recommend appropriate remedial measures to the issuer reflects a retreat from the Commission's initial position. Initially, the Commission proposed that the QLCC have the authority and the responsibility to "direct the issuer to adopt appropriate remedial measures." Proposing Release, supra note 58, at 86,528 . The change to merely recommending an appropriate response, as opposed to directing the adoption of the response, "responds to comments that the proposed rule would be in conflict with established corporate governance models insofar as the QLCC would have the explicit authority to compel a board of directors to take certain remedial actions." Adopting Release, supra note 59, at 87,082.

99. 17 C.F.R. $\$ 205.2(\mathrm{k})(2)$.

100. Id. $\S 205.2(\mathrm{k})(\mathrm{iii})(\mathrm{A})$.

101. Id. $\S 205.2(\mathrm{k})(3)(\mathrm{iii})(4)$.

102. Id. The rule does not, however, require the QLCC to notify the Commission of the issuer's failure. 


\section{A. The Impact of QLCCs on Attorneys as Gatekeepers}

Congress, in enacting Sarbanes-Oxley, focused primarily on improving corporate decisionmaking indirectly by increasing the accountability of gatekeepers-accountants, analysts, and attorneys. ${ }^{103}$ Accountants, and the auditing function they provide, are the principal focus of these efforts. Section 201, for example, prohibits auditors from providing specified non-audit services contemporaneously with an audit. ${ }^{104}$ Section 202 requires that the audit committee preapprove all substantive non-auditing services. ${ }^{105}$ Section 203 prohibits the lead audit partner from performing audit services for more than five consecutive years. ${ }^{106}$ Section 206 prohibits an auditor from performing services for an issuer if the chief executive officer, chief financial officer, controller, or chief accounting officer of the issuer was employed by the auditor within one year of the date of initiation of the audit. ${ }^{107}$ Congress further mandated, in section 204, that every auditor report directly to the audit committee all critical accounting policies and practices, all alternative treatments of financial information within generally accepted accounting principles that have been discussed with management, implications of their use, the auditor's preferred treatment of the information, and any written communication between the auditor and management. ${ }^{108}$

Sarbanes-Oxley also focuses on securities analysts and the research function that they provide. In section 501, Congress directed the Commission to adopt rules designed to mitigate the conflicts of interest that arise when analysts recommend stocks (and other equity securities) in research reports and through public appearances. ${ }^{109}$

103. A few provisions of Sarbanes-Oxley address management conduct. For example, section 304 requires the chief legal officer and the chief financial officer to reimburse the issuer for any bonus received and for any profit received from the sale of stock during the one-year period following the publication of financial information that, as a result of misconduct, fails to comply in a material way with any financial reporting requirement and so requires the preparation of an accounting restatement. Sarbanes-Oxley Act of 2002, § 304, 15 U.S.C.A. $\S$ 7243 (West Supp. 2003). Similarly, section 402 prohibits issuers from making personal loans to their executives and directors. $\S 402,15$ U.S.C.A. $\$ 78 \mathrm{~m}$.

104. $\$ 201,15$ U.S.C.A. $\$ 78 \mathrm{j}-1$.

105. $§ 202,15$ U.S.C.A. $\$ 78 \mathrm{j}-1$.

106. $\$ 203,15$ U.S.C.A. $\$ 78 \mathrm{j}-1$.

107. $\$ 206,15$ U.S.C.A. $\$ 78 \mathrm{j}-1$.

108. $\$ 204,15$ U.S.C.A. $\$ 78 \mathrm{j}-1$.

109. § 501, 15 U.S.C.A. § 78o-6. See generally Jill E. Fisch \& Hillary A. Sale, The Securities Analyst as Agent: Rethinking the Regulation of Analysts, 88 IOWA L. REV. 1035, 1076-77 (2003) (describing section 501). 
In the same vein, Congress sought to enhance the gatekeeping function of attorneys. ${ }^{110}$ Section 307 of Sarbanes-Oxley requires the Commission to adopt a regulatory framework in which attorneys are obligated to serve as gatekeepers for their clients by reporting evidence of misconduct up the corporate ladder. Although the reporting obligations imposed by Rule 205 implement the gatekeeping requirement specified by the statute, the Commission, at the same time, departed from the gatekeeping approach by introducing the QLCC. Specifically, a QLCC enables attorneys to escape the burden, and the risks, of the reporting obligations imposed by section 307 and Rule 205 merely by reporting evidence of misconduct to a committee of the board of directors.

How does the introduction of the QLCC undermine the role of attorneys as gatekeepers? Once an issuer has created a QLCC, an attorney may simply report evidence of misconduct to the committee. The attorney is relieved of any obligation to consider the strength of the evidence, the seriousness of the misconduct, or the appropriateness of the issuer's response. In addition, the attorney need not consider the impact of the report on the functioning of the committee or the issuer. The attorney need not evaluate the quality of the issuer's investigation of, and response to, the allegations in the report, and the attorney almost certainly will not participate in the formulation of the response. As the significance of the decision to make a report is reduced, the attorney may consider the decision to report less carefully. As a result, rather than assisting the issuer in identifying, investigating, and responding to misconduct, the attorney may overreport, leading to excessive indications of misbehavior, from the most trivial to the most grave, based on little independent investigation or analysis. ${ }^{111}$

The introduction of the QLCC shifts the responsibility for addressing misconduct from attorneys to the board. The QLCC bears all responsibility for compliance with Rule 205 , from receiving reports of misconduct, to probing the allegations contained in the reports, to

110. Note, however, that the notion that attorneys might serve as effective gatekeepers has provoked some degree of controversy. See, e.g., Coffee, supra note 3, at 1406-19 (describing the debate over the attorney's role as gatekeeper and advocating that the Commission adopt rules to enhance the gatekeeping function of attorneys); Fisch \& Rosen, supra note 16, at 1100 (questioning whether or not the gatekeeping function is consistent with the role of the securities lawyer).

111. See Fisch \& Rosen, supra note 16, at 1126-27 (warning that the reporting-up requirement may lead to overreporting by risk averse attorneys). 
designing appropriate remedial measures. Thus, the QLCC shifts the focus of reform efforts from gatekeepers to the board of directors.

The shift in focus from attorneys to independent directors is not necessarily misguided. ${ }^{112}$ Although some commentators have blamed gatekeepers for recent corporate governance scandals, others have faulted the structure and passivity of boards of directors. ${ }^{113}$ The gatekeeper model is controversial, and, indeed, some commentators have argued that advisors who provide professional services to issuers face pressures in the market that prevent them from operating as effective gatekeepers. ${ }^{114}$ Attorneys in particular may be poorly positioned to act as gatekeepers because, in addition to these market pressures, they lack the independence and information to monitor management in a meaningful way.

Moreover, rather than gatekeepers, state law has consistently emphasized the board of directors, and, particularly, the independent director, as the appropriate mechanism for monitoring management. ${ }^{115}$ Similarly, since the 1970 s, the Commission has consistently espoused the view that effective corporate governance is best achieved through increased reliance on monitoring by specialized

112. We do not argue that this shift in focus invalidates the portion of Rule 205 that creates the QLCC alternative. The QLCC is consistent with the general statutory objective of establishing governance mechanisms that reduce the risk of corporate misconduct. The statute explicitly endorses the role of specialist committees as one of these mechanisms by codifying the role of audit committees in section 301. Additionally, courts have generally deferred to the Commission's rulemaking efforts. But see Bus. Roundtable v. SEC, 905 F.2d 406, 407 (D.C. Cir. 1990) (rejecting the Commission's authority to promulgate a one share/one vote requirement based on its authority to regulate the proxy solicitation process).

113. These critics have posited that a lack of independence from managers and the failure to oversee the activities in which managers were engaged caused boards of directors to condone misconduct. See, e.g., Ide, supra note 3, at 839 (arguing that boards of directors failed to perform their oversight function because they "have developed a set of behaviors in which deference to, and rubber-stamping of, [chief executive officer] decision-making is the norm"); Stuart L. Gillan \& John D. Martin, Financial Engineering, Corporate Governance, and the Collapse of Enron 3 (The Center for Corporate Governance, Working Paper No. 2002-01, 2002), available at http://www.be.udel.edu/ccg/research_files/CCGWP2002-1.pdf (on file with the Duke Law Journal) (asserting that "a lack of board independence and oversight" was one of the primary reasons behind the collapse of Enron).

114. E.g., Ide, supra note 3, at 841 ("The culture of cross-selling and disclosed conflicts lead to complacent audits and aggressive accounting decision-making."); Gillan \& Martin, supra note 113, at 3-4 ("[T]he large consulting fees (relative to audit fees) received by auditors from the same client may compromise the auditor's independence.").

115. See, e.g., In re Walt Disney Co. Derivative Litig., 825 A.2d 275, 287-90 (Del. Ch. 2003) (emphasizing the importance of an independent board of directors exercising oversight regarding the decision to hire and then terminate executive Michael Ovitz). 
committees of independent directors. ${ }^{116}$ In particular, the Commission has directed its efforts to the structure and independence of the board of directors, ${ }^{117}$ and Commission rules have sought to divide board decisionmaking into specialized functions that are delegated to distinct board committees. ${ }^{118}$ For example, over the course of the past several decades, the Commission has focused on the audit committee, pushing issuers to create audit committees comprised of independent directors while, at the same time, increasing the authority and responsibility of these committees. ${ }^{119}$ The introduction of the QLCC is consistent with this approach.

Although a complete comparison of the relative merits of the approach embodied in Sarbanes-Oxley and the Commission's approach to corporate governance is beyond the scope of this Article, one observation is clear: the Commission has shifted the focus of the existing reform effort from gatekeepers to boards of directors. As we next explain, by implanting the QLCC within its attorney conduct rules and offering the committee as a means of reducing the burdens

116. See, e.g., H. Lowell Brown, The Corporate Director's Compliance Oversight Responsibility in the Post Caremark Era, 26 DEL. J. CORP. L. 1, 44-45 (2001) (describing the Commission's review of its rules pertaining to corporate governance and its conclusions, all focusing on board strength and director independence).

117. As the Commission explained in 1980, "[t]he board of directors has come to be viewed by many as the center of efforts to enhance corporate accountability. With an increased number of truly independent directors and an effectively functioning committee system, an institutionalized process for holding management accountable will be created." STAFF OF THE SEC, REPORT ON CORPORATE ACCOUNTABILITY 579 (Sept. 4, 1980).

118. See, e.g., Listed Company Audit Committee Release, supra note 65, at 87,402 (defining the standards for directors to be considered "independent" for purposes of membership on audit committees); Executive Compensation Disclosure, Exchange Act Release No. 31,327, [1992 Transfer Binder] Fed. Sec. L. Rep. (CCH) II85,056, at 83,414-31 (Oct. 16, 1992) (requiring compensation committees of boards of directors to prepare reports disclosing the basis for the compensation paid to executives (despite objections from commentators that disclosure is inappropriate)); Shareholder Communications, Shareholder Participation in the Corporate Electoral Process and Corporate Governance Generally; Final Rules, Securities Exchange Act Release No. 15,384, [1978 Transfer Binder] Fed. Sec. L. Rep. (CCH) I[81,766, at 81,088-99 (Dec. 6 , 1978) (amending the proxy rules to require greater disclosure of conflicts of interest, composition of standing committees of boards of directors, director attendance at meetings, and director resignations).

119. As with its initial efforts concerning audit committees, the Commission did not mandate the use of QLCCs. See Roberta S. Karmel, The Future of Corporate Governance Listing Requirements, 54 SMU L. REV. 325, 340-43 (2001) (describing the way the Commission effectively pressured the New York Stock Exchange to impose audit committee requirements through its listing standards). Rather, the Commission appears to be seeking to employ market forces and to enlist attorneys as mediating agents in an effort to apply indirect pressure to issuers to create QLCCs. The role of market forces in the implementation of QLCCs is described infra in Part II.B.2. 
and the risks imposed by Rule 205 on reporting attorneys, the Commission has also skewed the calculus faced by issuers in deciding whether or not to create QLCCs.

\section{B. The Factors Influencing Decisions To Create QLCCs}

1. The Benefits and Costs of QLCCs. The benefits and costs of creating a QLCC are, at this time, very speculative. The Commission's analysis of QLCCs focuses primarily on the advantages that these committees may confer on issuers and investors. Indeed, the Commission affirmatively "encourages issuers to [create QLCCs] as a means of effective corporate governance." ${ }^{120}$ In the Adopting Release, the Commission explains that "the QLCC institutionalizes the process of reviewing reported evidence of a possible material violation," ${ }^{121}$ characterizing this outcome as "a welcome development in itself." ${ }^{\prime 22}$ More specifically,

[t] he Commission believes that some issuers will choose to adopt QLCCs, and that they may prove to be a recognized and effective means of reviewing reported evidence of material violations. Because a QLCC must consist of at least two independent directors (as well as one member of the [issuer's] audit committee), it will give greater authority to independent directors. This should serve as an important check on corporate management. ${ }^{123}$

The Commission also reasons that the creation of a QLCC will provide a mechanism for independent directors to become involved in the process of evaluating allegations of misconduct. The extent to which these benefits will be realized depends critically on the viability of the Commission's preferred corporate governance model. In particular, QLCCs raise the question of whether allocating the responsibility for investigating and responding to reports of

120. Adopting Release, supra note 59, at 87,083.

121. Id. at 87,089 .

122. Id.

123. Id. at 87,101. Significantly, for purposes of the Paperwork Reduction Act of 1995, the Commission estimates that $20 \%$ of issuers will create QLCCs. Id. The rationale for this estimate is not clear. If the benefits of QLCCs outweigh the costs (as the Commission apparently believes), then we would expect most issuers to create them. Pressure from attorneys will only increase the number of issuers who create QLCCs. If, however, QLCCs impose substantial costs on issuers that are not recognized by the Commission (or described in the Adopting Release), then issuers will likely resist their creation. 
misconduct to a specialized committee of independent directors is an effective way of addressing misconduct.

The Commission has also indicated that the mere existence of a formalized and centralized mechanism will increase the likelihood that issuers will work within themselves to resolve reported occurrences of misconduct quickly. ${ }^{124}$ The technical details of the structure of the board of directors and its committees are unlikely, however, to dictate responsiveness. Rather, the extent to which directors respond promptly and appropriately to indications of misconduct is more likely to be a function of the issuer's "corporate culture" and the overall level of board involvement in corporate decisionmaking. If the issuer or the board of directors is already inclined to act forcefully, then the creation of a QLCC is unlikely to enhance or to hinder the willingness or ability to respond to reports of misconduct. If, on the other hand, the general approach is one of passivity, then the creation of a QLCC is unlikely to address this problem. The issuer's decision to create a QLCC might arguably modify its culture, serving to alter norms for reporting and responding to evidence of misconduct, but the extent of likely modification seems limited at best.

Finally, the Commission believes that QLCCs may help to increase investor confidence as

investors will know that [an issuer] that forms a QLCC will have reports of misconduct evaluated by at least one member of the [issuer's] audit committee as well as two or more of its independent directors. Investors will also know that if an issuer fails to implement a recommendation that the QLCC has recommended, the QLCC, after a majority vote, may notify the Commission. ${ }^{125}$

In light of the numerous scandals and widespread fraud involving issuers that had audit committees comprised of independent directors, it is highly debatable whether investors will be reassured by the creation of yet another independent board committee.

124. Id. at $87,100-01$.

125. Id. at 87,101 . 
At the same time, the creation of a QLCC is likely to entail substantial costs-costs that the Commission has not discussed. ${ }^{126}$ These costs include the costs of creating and maintaining the committee and the costs associated with the impact of the committee on the board of directors, including the functioning of the board of directors and the relationship between the board of directors and senior management.

The creation of a QLCC is likely to reduce an issuer's ability to attract qualified directors. Issuers have long expressed concern that, as the burdens associated with being a director increase, their success in attracting and retaining qualified directors decreases. ${ }^{127}$ The creation of a QLCC clearly increases the burdens associated with serving on a board of directors. ${ }^{128}$ In particular, serving on the QLCC would require an extensive commitment of time and effort and would likely increase the director's exposure to liability and litigation. ${ }^{129}$ The

126. The Commission notes only that issuers who "choose to form a QLCC ... will incur costs. These costs might include increased compensation and insurance for QLCC members, and the administrative costs to establish the committee." Adopting Release, supra note 59, at 87,101 .

127. See, e.g., 138 CONG. REC. S12,599 (daily ed. Aug. 12, 1992) (statement of Sen. Domenici) (arguing that excessive securities fraud litigation hurts the ability of American businesses to attract competent board directors); Lucian A. Bebchuk \& Assaf Hamdani, Optimal Defaults for Corporate Law Evolution, 96 Nw. U. L. REV. 489, 507 (2002) (noting that decisions indicating a greater willingness by courts to find directors liable for breaches of fiduciary duty "led to a widespread concern that companies might be unable to attract qualified individuals to serve on their boards of directors"); Thomas Lee Hazen, Observation: Corporate Directors' Accountability: The Race to the Bottom-The Second Lap, 66 N.C. L. REV. 171, 179 (1987) (calling the "feared inability to attract good directors" due to difficulties in securing insurance "a real concern").

128. Indeed, commentators have argued that "the new rules may make it harder for [issuers] to recruit effective board members." Andrew Osterland, Board Games, CFO MaGAzINE, Nov. 1,2002 , at 34,36 .

129. As one commentator notes, the responsibilities of the QLCC “impose[] a personal burden on ... non-employee directors that goes far beyond anything that can reasonably be requested of them." Letter from Clifford Chance US LLP, to Jonathan G. Katz, Secretary, SEC 6 (Dec. 18, 2002) (on file with the Duke Law Journal). See Symposium, Lessons from Enron: A Symposium on Corporate Governance, 54 MERCER L. REV. 731, 748 (2003) (inquiry of Michael Rosenzweig) ("[W]hy would these independent, professional, capable individuals want to serve on these boards when one remembers that in this new world of corporate responsibility, they've got dramatically increased authority, dramatically increased responsibility . . . [and] significantly increased exposure, therefore, to liability?"); Michael Schroeder, Cleaner Living, No Easy Riches: Critics Say Sarbanes-Oxley Law Hobbles Stocks, Chills Risk Taking, but Upshot Is Far Less Dramatic, WALL ST. J., July 22, 2003, at C1 ("Top executives have been wringing their hands about Sarbanes-Oxley's potential to create a shortage of candidates to fill board seats."); Letter from Clifford Chance, to Jonathan G. Katz, supra, at 6 (stating belief that issuers "will have great difficulty in finding non-employee directors who will be willing to serve on QLCCs"). 
burden is multiplied in cases in which the issuer's audit committee also serves as the QLCC. ${ }^{130}$ Service on a QLCC will require directors to design an appropriate reporting system, develop procedures for investigating reports, and establish standards for evaluating the results of those investigations and deciding on appropriate remedial action. The burden associated with processing reports of misconduct will be exacerbated to the extent that attorneys face incentives to report all possible indications of misconduct to the QLCC. ${ }^{131}$ The work of the committee is likely to involve difficult questions of law. Members of the QLCC may lack familiarity with legal issues, particularly if the QLCC is simply the audit committee, for which directors are chosen for their financial rather than legal expertise. ${ }^{132}$ Finally, service on the committee may increase the liability exposure of QLCC members relative to other members of the board of directors. ${ }^{133}$

130. See, e.g., Symposium, supra note 129, at 748 (inquiry of Michael Rosenzweig) (noting that directors will be "spending lots more time, especially if you're lucky enough to be on the audit committee, or the compensation committee, or the nominating committee"); Schroeder, supra note 129 (describing Sarbanes-Oxley as requiring "additional work, responsibilities and obligations on the part of the outside auditor, management and the audit committee") (quoting William F. Ezzell, chairman of the American Institute of Certified Public Accountants).

131. See Letter from Los Angeles County Bar Association to Jonathan G. Katz, Secretary, SEC 6 (Dec. 18, 2002) (on file with the Duke Law Journal) ("The low threshold requiring an attorney to report 'evidence of a material violation' could easily create a large flow of information to the chief legal officer or qualified legal compliance committee which could [create an expensive and unwieldy process].").

132. See, e.g., Donald C. Langevoort, The Human Nature of Corporate Boards: Law, Norms, and the Unintended Consequences of Independence and Accountability, 89 GEO. L.J. 797, 823 (2001) ("Most directors are not lawyers, and have little or no first-hand knowledge of legal rules.").

133. See, e.g., Symposium, supra note 129, at 748 (inquiry of Michael Rosenzweig) (identifying the likelihood that service on the audit, nominating, or compensation committee means "bottom line, significantly increased exposure ... to liability"). 
The costs of maintaining a QLCC will obviously vary according to factors such as the size of the issuer, the nature of the issuer's business, and the composition of the board of directors. These costs include the compensation that issuers must pay their committee members. Given the increased obligations and liability exposure faced by QLCC members, issuers may need to compensate QLCC members more highly than other directors. ${ }^{134}$ Issuers may face higher costs in obtaining directors and officers insurance, especially if QLCC members are targeted in litigation more frequently, even if they do not ultimately face greater liability exposure than other directors. ${ }^{135}$ Each issuer will also face opportunity costs, in that the work associated with the QLCC will take away from the time independent directors are able to devote to overseeing other aspects of the issuer's affairs. ${ }^{136}$ Independent directors, in particular, have limited time to devote to their director's duties. Even if serving on the QLCC causes them to increase the number of hours they devote to the issuer's affairs, their responsibilities on the QLCC may reduce their ability to provide other valuable services to the issuer, including strategic planning and selecting and evaluating senior management.

134. See, e.g., id. at 752 (inquiry of Judge Benjamin F. Tennille) ("You get what you incentivize, and the way you structure director compensation has got to be based on what you want to give directors the incentive to do. If you want them to spend more time, you pay them for the time they spend.").

135. See, e.g., id. at 748 (inquiry of Michael Rosenzweig) ("[I]t's increasingly difficult to secure adequate directors and officers liability insurance coverage, and that once it is secured those $\mathrm{D} \& \mathrm{O}$ companies increasingly deny coverage, or seek to deny coverage, when claims are actually made."); Theo J. Francis, It Still Costs Big to Insure Against a Boardroom Scandal: Despite the Sarbanes-Oxley Bill, "D\&O" Policy Prices Rise 30\%, and Cancellation Clauses Swell, WALL ST. J., July 31, 2003, at C1 (stating that:

a year after Congress legislated responsibilities for corporate boards and officers, aiming to make corporate scandal less likely, rates for what is known as 'directors and officers' liability insurance are still rising-albeit at a slower pace-and the terms of the coverage remain stingier than just a few years back

and noting that "now, annual increases are more in the $25 \%$ to $30 \%$ range"); Letter from Sean M. Fitzpatrick, Chief Underwriting Officer, Chubb Specialty Insurance, to Jonathan G. Katz, Secretary, SEC 3 (Dec. 17, 2002) (on file with the Duke Law Journal) (stating that because professional liability exposures such as those arising under Rule 205 "have traditionally been viewed as outside the normal duties of a director or officer for purposes of D\&O insurance, there will be significant reluctance on the part of underwriters to include this type of risk in D\&O coverage absent substantial additional premium”).

136. See, e.g., Carol Hymowitz \& Joan S. Lublin, Boardrooms Under Renovation: Scandals Prompted Changes but Critics Say More Are Needed to Prevent Another Enron, Wall St. J., July 22, 2003, at B1 (noting that directors "sometimes find themselves spending too much time listening to advisers, rather than attending to the [issuer's] business"). 
The creation of a QLCC will also affect relationships among directors and between the board of directors and senior management. State law has traditionally treated the board of directors as a collegial body. ${ }^{137}$ Directors act collectively, and they have generally been held to lack the authority to act for the issuer in their individual capacities. ${ }^{138}$ Although boards of directors have the power to create special committees and to delegate decisionmaking authority to those committees, ${ }^{139}$ a distinction exists between a voluntary board decision to create a committee, which may be modified or abolished at any time, and a regulation that imposes "long term structural powerrelated distinctions between different groups of directors of the same board." "140

The QLCC is likely to disrupt the collective decisionmaking structure of the collegial board. Because of their work on the committee, members of the QLCC will have greater information and perhaps be better compensated than the other directors. In effect, the members of the QLCC will be specialist directors. Their specialist status may interfere with their ability to participate in collective decisionmaking. For example, their superior knowledge of the issuer's affairs and their devotion of greater time to the issuer's operations may lead them to demand deference from the other nonspecialist directors. In addition, the nonspecialist directors may resent the higher pay or greater access to information possessed by QLCC members, and this resentment may lead them to be less involved in the affairs of the issuer. In this way, the differences between members of the QLCC and other directors may impair the ability of the board of directors to function effectively. ${ }^{141}$

With respect to the relationship between the board of directors and senior management, it is important to recognize that the

137. See Stephen M. Bainbridge, Why a Board? Group Decisionmaking in Corporate Governance, 55 VAND. L. REV. 1, 45 (2002) (describing the board of directors as a "collegial body that, for the most part, makes decisions by consensus").

138. See, e.g., Melvin A. EISEnberg, Corporations AND Other Business ORGANIZATIONS 206 (8th ed. 2000) ("A single director, as such, has no power. Instead, directors can act only as a body.").

139. See, e.g., DEL. CODE ANN. tit. 8, § 141(c) (2001) ("The board of directors may, by resolution passed by a majority of the whole board, designate 1 or more committees ...."); N.Y. BUS. CORP. LAW $\S 712$ (a) (2003) (“[T]he board, by resolution adopted by a majority of the entire board, may designate from among its members an executive committee ....”).

140. Carmody v. Toll Brothers, 723 A.2d 1180, 1192 (Del. Ch. 1998).

141. See, e.g., Langevoort, supra note 132, at 800 (arguing that differences among directors "interfere[] with the board as a productive team in all its capacities"). 
creation of a QLCC will create a governance structure that functions independently of management. The QLCC will receive reports of misconduct, investigate the allegations contained in the reports, and respond to those allegations without involving, or even consulting with, management. Indeed, Rule 205 explicitly requires the QLCC to establish procedures for maintaining the confidentiality of reports that it receives, ${ }^{142}$ presumably as an attempt to insulate reporting attorneys from management retaliation. As a result, management may not even have knowledge of the work of the QLCC. Exclusion of management, particularly the chief executive officer, from important work of the issuer generally and the board of directors specifically is wholly inconsistent with the normal operation of both the issuer and the board of directors. Ironically, it is also inconsistent with the requirement of Sarbanes-Oxley that the issuer's chief executive officer and chief financial officer affirmatively certify their familiarity with the issuer's internal controls and any deficiencies in those controls. ${ }^{143}$

Management, particularly the chief executive officer, is thus likely to resist the creation of a QLCC. If the issuer decides, nonetheless, to establish a QLCC, management is likely to mistrust its activities and fail to support investigations in which it is engaged, particularly because management will not be fully informed of the subject of the investigations. Similarly, a concern about the QLCC's investigative role and potentially antagonistic relationship with management may lead management to share less information with the board of directors as a whole. ${ }^{144}$ For example, the chief executive officer may become reluctant to seek the advice of members of the board of directors, particularly those serving on the QLCC, regarding concerns related to the accounting methods used to record the revenues of a new business. At the same time, management's lack of access to early warnings of potential problems within the issuer may impair its ability to run the issuer's business effectively. For example, the chief executive officer may be preparing to promote an executive while, at the same time, the QLCC is investigating that executive's role in alleged misconduct.

142. 17 C.F.R. $\S 205.2(\mathrm{k})(2)(2003)$.

143. Sarbanes-Oxley Act of $2002 \S 302,15$ U.S.C.A. $\$ 7241$ (West Supp. 2003).

144. See Jill E. Fisch, Taking Boards Seriously, 19 CARDOzo L. Rev. 265, 281 (1997) ("A board that maintains a greater distance may risk inadequately understanding the company it is attempting to monitor."). 
2. The Role of Attorneys. In analyzing the benefits and costs associated with QLCCs, issuers are likely to rely heavily on the Commission's encouragement and their attorneys' advice. Attorneys play an increasingly important role in mediating ambiguous or complex legal issues for their clients. ${ }^{145}$ The role of attorneys as mediating agents with respect to an issuer's decision to create a QLCC is particularly problematic due to the advantages that QLCCs provide to attorneys who represent issuers.

As Professor John Coates explains, the division of labor between attorneys and corporate clients causes clients to rely on their attorneys to evaluate the effect of choices in governance structures and to implement those choices through the drafting of appropriate legal documents. ${ }^{146}$ Professor Kim Krawiec has applied this analysis to the specific issue of corporate compliance, finding that clients are driven by their attorneys to adopt structural reforms such as written codes of conduct and reporting procedures. ${ }^{147}$ Similarly, Professor Coates demonstrates that attorneys are the motivating force in the adoption of takeover defensive structures. ${ }^{148}$

Client reliance on attorneys as mediating agents can be problematic. Attorneys may act out of self-interest or ignorance, thereby failing to provide their clients with the best advice, an issue of particular importance with respect to decisions regarding governance structures that are based primarily on nonlegal considerations. For example, Professor Krawiec warns that, in many cases, structural reforms advocated by attorneys are of uncertain value in improving compliance. ${ }^{149}$ Similarly, Professor Coates concludes that differences in the sophistication of attorneys or practice norms, rather than efficiency concerns, govern variations in corporate governance structures. ${ }^{150}$ In addition, Professor Coates finds that attorneys consistently make errors in implementing their choices regarding

145. See John C. Coates IV, Explaining Variation in Takeover Defenses: Blame the Lawyers, 89 CAL. L. REV. 1301, 1304 (2001) (finding "strong evidence" that attorneys determine key governance terms in corporate contracts relating to the adoption of takeover defenses).

146. See id. at 1309-11 (describing division of labor between attorney and client with respect to governance choices as "a classic agency relationship").

147. Kimberly D. Krawiec, Cosmetic Compliance: An Incomplete Contracts Governance Theory, 81 WASH. U. L. Q. 487, 500-03 (2003).

148. Coates, supra note 145, at 1304.

149. See Krawiec, supra note 147, at 510 ("[L]ittle evidence exists at all concerning the effectiveness of internal compliance structures as a means to reduce socially harmful conduct.").

150. Coates, supra note 145, at 1382. 
takeover defensive structures. ${ }^{151}$ This work shows both that attorneys have substantial influence over the governance structures adopted by their issuer clients and that there is a risk that this influence will not lead to the adoption of the best structures.

Attorney-driven decisions on issuer creation of QLCCs engender a particular risk that an issuer's needs will be poorly served because of the substantial benefits that QLCCs provide to reporting attorneys. Specifically, the creation of a QLCC is likely to relieve the burden and reduce the risk associated with the reporting requirements of Rule 205. This relief is especially significant in the case of outside attorneys retained by the issuer. These attorneys face less work, uncertainty, and exposure to liability when reporting to a QLCC. For a chief legal officer, the creation of a QLCC is also likely to relieve the burden and reduce the risk associated with conducting an inquiry into a report of misconduct. As a result, outside counsel, and perhaps in-house counsel as well, may pressure issuers to create QLCCs. One commentator has observed that attorneys "may even insist that their corporate clients establish QLCCs." 152

Consider first the obligations of a reporting attorney. If an issuer has an appropriately constituted QLCC in place, the attorney is able to satisfy fully the reporting obligations under Rule 205 simply by reporting to the QLCC. As a result, the reporting attorney is relieved both of the obligation to determine whether or not the issuer has responded appropriately to the report and, if the determination is that the response is not appropriate, of the obligation to report the matter up the ladder. Moreover, although the Commission has not adopted final rules concerning the attorney's obligation to withdraw from representation of the issuer, under the current proposals, the attorney's obligation is not triggered if the attorney reports to a QLCC. ${ }^{153}$ Because the reporting attorney need not exercise judgment in evaluating the timeliness or appropriateness of the issuer's response and the attorney need not make any additional reports or withdraw from representation, the attorney's potential liability is limited after reporting to a QLCC.

151. See id. at 1368-69 (describing a large number of "gaffes" in initial governance structures).

152. Letter from Richard W. Painter, Visiting Professor of Law, University of Michigan Law School, to Jonathan G. Katz, Secretary, SEC 5 (Dec. 12, 2002), available at http://www.sec.gov/rules/proposed/s74502/rwpainter1.htm (on file with the Duke Law Journal).

153. Proposing Release, supra note 58, at 86,541; Second Proposing Release, supra note 74, at 87,115 . 
In contrast, if an issuer does not have a QLCC in place, the reporting attorney must not only report to the issuer's chief legal officer, but the reporting attorney must also be satisfied that the issuer's response to the report is received within a reasonable period of time and is appropriate. ${ }^{154}$ In the event the reporting attorney does not receive an appropriate response within a reasonable period of time, the reporting attorney must report the matter to others within the issuer. ${ }^{155}$ These requirements create additional work for the attorney in monitoring the situation and expose the attorney to liability in applying the new (and confusing) ${ }^{156}$ regulatory standard to determine whether or not the issuer has responded appropriately.

The additional burden and risk associated with evaluating the timeliness and appropriateness of an issuer's response are likely to be significant, especially in the case of outside counsel ${ }^{157}$ Despite diligent efforts, outside counsel will often lack both information regarding the issuer's affairs and knowledge of the issuer's decisionmaking process. As a result, outside counsel will face severe difficulties in applying the standard-that is, in developing a reasonable belief that no misconduct has occurred, is occurring, or is about to occur, in determining that the issuer has adopted appropriate remedial measures, or in evaluating the work of an investigating attorney and the issuer's response to the investigating attorney's recommendation. Outside counsel will also face a conflict in that any disagreement with the issuer about the scope of the response is likely to impair future business relationships, if the initial report has not already destroyed those relationships. ${ }^{158}$ Finally, in addition to liability for violations of

154. 17 C.F.R. $\S 205.3(b)(3)$ (2003).

155. Id.

156. As one commentator notes, the definition of the term "appropriate response" is "ambiguous and raises significant uncertainty." Letter from Richard Hall, Partner, Cravath, Swaine \& Moore, to Jonathan G. Katz, Secretary, SEC 4 (Dec. 18, 2002) (on file with the Duke Law Journal).

157. The burden and risk may also be significant for in-house counsel. Although in-house counsel is likely to possess better information regarding the issuer than outside counsel and to be better able than outside counsel to monitor the issuer's decisionmaking process, in-house counsel will face an important conflict in that, despite the "whistleblower" protections included in section 806 of Sarbanes-Oxley, 15 U.S.C.A. $\$ 7245$ (West Supp. 2003), any disagreement with management regarding the issuer's response is likely to impair counsel's employment (or at least promotion and discretionary pay). In-house counsel will also face the same risks of securities liability and claims of malpractice as outside counsel.

158. See Fisch \& Rosen, supra note 16, at 1127-28 (arguing that the reporting up requirement will jeopardize counsel's business relationship with the issuer). 
the securities laws, counsel faces the risk of malpractice claims. ${ }^{159}$ This risk is magnified by the Commission's characterization of Rule 205's reporting obligation as part of the duties owed to the issuer as a client. ${ }^{160}$

Now consider the obligations of a chief legal officer. If an appropriately constituted QLCC is in place, a chief legal officer may refer any report of a material violation or a material breach to the QLCC. ${ }^{161}$ Once a report is referred to the QLCC, the chief legal officer is relieved of the obligation to conduct an investigation concerning the reported misconduct. ${ }^{162}$ In contrast, if an issuer does not have a QLCC in place, then the chief legal officer must conduct the investigation and take all reasonable steps to cause the issuer to adopt an appropriate response to the report. ${ }^{163}$ Most importantly, referral to the QLCC relieves the chief legal officer of the risk of a subsequent determination, with the benefit of hindsight, that the reported misconduct was not investigated properly. In light of the potential liability now facing Vinson \& Elkins in connection with its

159. As one commentator notes, Rule 205 "will increase both the frequency and severity of malpractice claims against attorneys, by creating a higher volume of regulatory enforcement actions by the Commission and by creating the basis for more traditional malpractice claims." Letter from Sean M. Fitzpatrick, Chief Underwriting Officer, Chubb Specialty Insurance, to Jonathan G. Katz, Secretary, SEC 3, supra note 135, at 2. Along with the increased malpractice risk, counsel will also likely face increased costs of malpractice insurance. Indeed, because "the vast majority of lawyers professional liability policies . . . exclude" coverage for disciplinary or grievance proceedings, and further exclude from the definition of covered loss fines, sanctions, costs, and penalties, law "firms will not have coverage for the costs of defending disciplinary proceedings by the Commission under the [p]roposed [r]ule [or Rule 205], nor for any penalties assessed in such proceedings. Such coverage would be available, if at all, only for a substantial additional premium ...." Id. at 3 .

160. Rule 205.3 provides that "[a]n attorney appearing and practicing before the Commission in the representation of an issuer owes his or her professional and ethical duties to the issuer as an organization.” 17 C.F.R. $§ 205.3$ (a). Although Rule 205.7 states that nothing in the rule "is intended to, or does, create a private right of action against any attorney, law firm, or issuer based upon compliance or noncompliance with its provisions," Id. $\S 205.7$, shareholders are presumably free to enforce the issuer's rights against attorneys through derivative litigation.

161. Id. $\$ 205.3(\mathrm{c})(2)$.

162. Id.

163. Id. $\$ 205.3(\mathrm{~b})(2)$. 
investigation of reported wrongdoing at Enron, ${ }^{164}$ this risk is not insubstantial.

For all attorneys, then, the creation of a QLCC is likely to reduce the burdens and risks associated with the requirements of Rule 205. In addition to recognizing these significant benefits, attorneys are also likely to view the QLCC as a mechanism for facilitating their traditional roles as advisors and "transaction cost engineers." ${ }^{165}$ In other words, the QLCC, by reducing attorneys' obligations as gatekeepers, will allow them to focus on providing legal advice and structuring transactions. This effect is increased by the confidentiality accorded to the QLCC's investigations, which reduces the risk that an attorney's reports of corporate misconduct will result in dismissal from representation and loss of business. ${ }^{166}$

Due to the fact that attorneys will retain the choice, with respect to an issuer that has created a QLCC, between reporting evidence of misconduct to the QLCC or to the issuer's chief legal officer or chief executive officer, the QLCC may also provide attorneys with additional leverage. An attorney may approach the chief legal officer, for example, and threaten to report evidence of misconduct to the QLCC unless the attorney receives assurances of retention in future matters. An in-house attorney, or even the chief legal officer, could use a similar threat to secure job protection from the chief executive officer. Because management reasonably needs and wants to be informed of potential misconduct and to be involved in the investigation of the allegations (rather than leaving the investigation to independent directors), management is likely to be responsive to these threats.

Consequently, attorneys may pressure their issuer clients and potential clients to create QLCCs. Issuers that refuse to establish QLCCs may find themselves disadvantaged in the market for legal services. Attorneys, especially those at elite law firms, may refuse

164. See, e.g., Kurt Eichenwald, Enron's Many Strands: Another Inquiry; Company Hobbled Investigation by Its Law Firm, Report Says, N.Y. TIMES, Feb. 4, 2002, at A19. (quoting the Powers' Report conclusion that Vinson \& Elkins' investigation was "inadequate" and that its findings were "largely predetermined by the scope and nature of the investigation and the process employed").

165. For a discussion of this role of attorneys, see Ronald J. Gilson, Value Creation by Business Lawyers: Legal Skills and Asset Pricing, 94 YALE L.J. 239 (1984).

166. See Fisch \& Rosen, supra note 16, at 1125-26 (identifying the potential adverse professional consequences faced by lawyers who report up in accordance with the requirements of Sarbanes-Oxley section 307). 
engagements with issuers who do not have QLCCs. Indeed, one plausible rationale for the regulatory structure adopted in Rule 205 is to provide market-based incentives for issuers to create QLCCs. ${ }^{167}$ Importantly, however, attorney pressure on issuers to establish QLCCs may reflect the benefits to attorneys from the creation of QLCCs, rather than the benefits to issuers.

Finally, even if QLCCs are a desirable governance practice for issuers, they may impose costs on the capital markets. Historically, issuers have been able to signal to investors the quality of their management, the monitoring provided by their board of directors, and their internal controls, by adopting "high quality" governance structures such as independent boards of directors and active audit committees. ${ }^{168}$ To the extent that the Commission mandates specific governance structures, directly or indirectly, it reduces the ability of issuers to signal high quality by voluntarily choosing these structures. Any reduction in the ability of issuers to signal their quality to investors reduces the transparency of the capital markets, and any reduction in transparency reduces the ability of the capital markets to price securities accurately. ${ }^{169}$

167. As one group of commentators notes:

$[\mathrm{M}]$ any public companies are likely to adopt the QLCC procedure for reporting evidence of material violations because the use of this procedure satisfies the report obligation of a reporting attorney, relieves that attorney of the duty to effect a "noisy withdrawal," and relieves the [chief legal officer] of the duty to conduct his own inquiry.

Letter from Susan P. Koniak and Other Law Professors, to Jonathan G. Katz, Secretary, SEC 11 (Dec. 17, 2002) (on file with Duke Law Journal). In addition, these commentators note "the practical reality that many or most large public companies will adopt the alternative reporting procedures provided in $\S 205.3(\mathrm{c})$." Id. at 21 .

168. For example, Professor John Coffee has recently pointed out that foreign issuers may list their securities on U.S. securities exchanges as a means of subjecting themselves to the higher disclosure standards, and greater threat of enforcement, of the U.S. markets and of credibly signaling their intention to make fuller disclosure, thereby achieving a higher market valuation and a lower cost of capital. John C. Coffee, Jr., Racing Towards the Top?: The Impact of Cross-Listing and Stock Market Competition on International Corporate Governance, 102 COLUM. L. REV. 1757, 1797 (2002). Similarly, issuers may adopt high quality governance structures as a means of credibly signaling their intention to provide effective controls on management.

169. See, e.g., Stephen A. Ross Et AL., Corporate Finance 342-43 (6th ed. 2002) (describing the role of efficient capital markets in incorporating information into the prices of stocks). 
This analysis does not mean that the costs of QLCCs necessarily outweigh the benefits. The potential effectiveness of QLCCs in addressing misconduct is unproven. Ultimately the Commission's predictions about the value of QLCCs may be borne out. In the absence of experience with QLCCs, the calculus is highly uncertain. We simply observe here that the Commission has not discussed in any detail the costs of QLCCs and that the benefits of QLCCs for attorneys are likely to increase pressure on issuers to adopt QLCCs, independent of the issuer's own calculation of the benefits and costs.

From the issuer's (and the public's) perspective, the key question is whether QLCCs are likely to be successful in preventing, or at least limiting, corporate misconduct. Although the absence of experience with QLCCs makes it impossible to answer this question directly, some insight may be drawn from the audit committee experience. Compelling analogies exist between the QLCC and the audit committee. Accordingly, we next turn our attention to the experience with audit committees.

\section{Lessons from Audit Committees}

The Commission has a long history of implementing its vision of corporate governance reform. This vision, which focuses on monitoring by independent directors, relies on revisions to the structure of the board of directors and the adoption of specialized board committees. As with recent initiatives regarding QLCCs, the Commission's actions regarding audit committees over the course of the past sixty years reflect an attempt to divide board decisionmaking into separate functions that are delegated to distinct committees comprised of specialist directors. In many ways, QLCCs resemble audit committees, particularly in their composition and their intended role in enhancing the monitoring role of the board of directors. Consequently, the historical experience with audit committees is instructive in predicting the likely effectiveness of QLCCs. 
1. The Experience with Audit Committees. The Commission first identified the use of audit committees as a valuable regulatory objective in the 1940s. ${ }^{170}$ Subsequently, in connection with its examination of corporate governance practices in the 1970s, the Commission focused specifically on audit committees. The Commission did not initially attempt to mandate the use of audit committees, presumably taking the view that such an attempt would have been inconsistent with the traditional division between state and federal regulatory authority. ${ }^{171}$ Instead, the Commission used its supervisory power over self-regulatory organizations, including the New York Stock Exchange, Inc. (NYSE) and the Nasdaq Stock Market, Inc., (Nasdaq), to encourage them to impose audit committee requirements. ${ }^{172}$ The NYSE and the Nasdaq responded to Commission pressure by recommending and ultimately requiring, through their listing standards, that issuers establish independent audit committees. ${ }^{173}$

Thus, in 1972, the Commission issued a release endorsing "the establishment by all publicly-held companies of audit committees composed of outside directors." ${ }^{\text {174 }}$ The NYSE responded by recommending that listed companies create audit committees comprised of outside directors. ${ }^{175}$ In 1974, the Commission amended its proxy disclosure rules to require issuers to disclose the presence or

170. Listed Company Audit Committee Release, supra note 65, at 87,404, n.17; see also Roberta S. Karmel, The Independent Corporate Board: A Means to What End?, 52 GEO. WASH. L. REV. 534, 545 (1984) (describing the history of the Commission's effort to implement independent audit committees); Helen S. Scott, The SEC, the Audit Committee Rules, and the Marketplaces: Corporate Governance and the Future, 79 WASH. U. L. Q. 549, 551 (2001) ("Since the early 1940s, the Commission, along with the auditing and corporate communities, has had a continuing interest in promoting effective and independent audit committees.") (citing Audit Committee Disclosure, Exchange Act Release No. 41,987, [1999-2000 Transfer Binder] Fed. Sec. L. Rep. (CCH) II 86,209, at 82,409 (Oct. 7, 1999) [hereinafter Audit Committee Disclosure Release].

171. See Bus. Roundtable v. SEC, 905 F.2d 406, 407 (D.C. Cir. 1990) (striking down one share/one vote rule as beyond the Commission's authority).

172. Karmel, supra note 119, at 340; Scott, supra note 170, at 554.

173. Scott, supra note 170 , at 554 .

174. Standing Audit Committees Composed of Outside Directors, Exchange Act Release No. 9,548, [1971-1972 Transfer Binder] Fed. Sec. L. Rep. (CCH) II 78,670, at 81,424 (Mar. 23, 1972).

175. Karmel, supra note 119, at 329 (attributing the evolution of the NYSE's independence requirement for audit committee members to pressure from the Commission). 
absence of audit committees. ${ }^{176}$ The NYSE responded in 1977, amending its rules to mandate that all listed domestic companies create and maintain "audit committee[s] comprised solely of directors independent of management and free from any relationship that ... would interfere with [their] exercise of independent judgment." ${ }^{177}$ Throughout the 1970s and 1980s, the Commission's focus on accounting and financial controls increased, aided by various statutory developments endorsing the Commission's policy perspective..$^{178}$

The focus on audit committees has continued. In 1998, in response to Commission Chairman Arthur Levitt's public complaints about audit committee composition and independence, ${ }^{179}$ the NYSE and the Nasdaq tightened their respective listing standards, requiring audit committees to consist of at least three members, each of whom is independent and financially literate, with at least one member having accounting or financial expertise. ${ }^{180}$ In addition, the rules require each audit committee to have the right to hire and to fire the

176. Notice of Amendments to Require Increased Disclosure of Relationships Between Registrants and Their Independent Public Accountants, Exchange Act Release No. 11,147, [Accounting Series Release Transfer Binder] Fed. Sec. L. Rep. (CCH) II 72,187, at 62,394 (Dec. 20, 1974).

177. New York Stock Exchange, Inc., Exchange Act Release No. 13,346, 1977 SEC LEXIS 2252, at *1 (March 9, 1977).

178. See John F. Olson, How to Really Make Audit Committees More Effective, 54 Bus. LAW. 1097, 1097-98 (1999) (tracing statutory developments from the enactment of the Foreign Corrupt Practices Act of 1977, Pub. L. No. 95-213, 91 Stat. 1494 (codified as amended in scattered sections of 15 U.S.C.), to federal banking legislation requiring independent audit committees for large financial institutions, Federal Deposit Insurance Corporation Improvement Act of $1991 \S 112,12$ U.S.C. $§ 1831 \mathrm{~m}(\mathrm{~g})(1)(\mathrm{A})$, (j)(1) (2000)).

179. Arthur Levitt, The "Numbers Game," Remarks at the New York University Center for Law and Business (Sept. 28, 1998), at http://www.sec.gov/news/speech/speecharchive/1998/ spch220.txt (on file with the Duke Law Journal); see also Scott, supra note 170, at 552-57 (describing the role of the Commission, and Chairman Levitt, in providing the impetus for the adoption of new listing standards by the NYSE and Nasdaq).

180. Self-Regulating Organizations; Order Approving Proposed Rule Change by the New York Stock Exchange, Inc., Exchange Act Release No. 42,233, 1999 SEC LEXIS 2645, at *6-7 (Dec. 14, 1999) [hereinafter NYSE Release]; Self-Regulatory Organizations; Order Approving Proposed Rule Change by the National Association of Securities Dealers, Inc., Exchange Act Release No. 42,231, 1999 SEC LEXIS 2655, at*8-9 (Dec. 14, 1999) [hereinafter Nasdaq Release]. 
issuer's auditor. ${ }^{181}$ At the same time, the Commission revised the rules mandating disclosure of audit committee activities. ${ }^{182}$

The following year, the Commission adopted more stringent disclosure requirements that, in effect, dictate the structure and operation of audit committees by requiring issuers to disclose the extent to which the operation of their audit committees meets the regulatory standards. ${ }^{183}$ Most recently, the Commission, as mandated by section 301 of Sarbanes-Oxley, ${ }^{184}$ directed the NYSE and the Nasdaq (together with the other national securities exchanges and associations) to adopt rules prohibiting the listing of any security of any issuer that is not in compliance with specified requirements relating to the independence, authority, responsibility, functioning, and funding of expenses of audit committees. ${ }^{185}$

2. The Audit Committee Analogy. As this brief history of the audit committee demonstrates, audit committees and QLCCs share many similarities even with respect to the Commission's role in their adoption. The Commission identified the audit committee as a desirable governance structure and subsequently enlisted the selfregulatory organizations to encourage issuers to create audit committees. By the same token, Rule 205 describes the Commission's position concerning the benefits of the QLCC and seeks to induce issuers to create QLCCs voluntarily.

Moreover, QLCCs and audit committees reflect similar types of governance structures. Both are independent board committees comprised of specialist directors, that is, independent directors who,

181. NYSE Release, supra note 180 , at $* 5$; Nasdaq Release, supra note 180 , at *8. See also Listed Company Audit Committee Release, supra note 65, at 87,405 (noting revision of listing standards related to audit committees by NYSE and Nasdaq); Scott, supra note 170, at 557-66 (describing adoption of rules by NYSE and Nasdaq).

182. See Audit Committee Disclosure Release, supra note 170, at 82,884 (adopting disclosure requirements). See also Listed Company Audit Committee Release, supra note 65, at 87,405-06 (noting adoption of new rules by the Commission requiring disclosure of the function, governance, and independence of audit committees).

183. See Audit Committee Disclosure Release, supra note 170, at 82,885 (requiring, inter alia, each audit committee to "disclose" whether it has followed various procedures in connection with the preparation of the issuer's financial statements, and each issuer to "disclose" whether its audit committee has a written charter and whether the members of its audit committee are independent directors).

184. Sarbanes-Oxley Act of $2002 \S 301,15$ U.S.C.A. 78j-1 (West Supp. 2003).

185. See Listed Company Audit Committee Release, supra note 65, at 87,402 (implementing the requirements of section 10A of the Securities Exchange Act of 1934, 15 U.S.C. § 78j-1, as amended by $\S 301,15$ U.S.C.A. $78 j-1)$. 
through their work on the relevant committee, are expected to develop expertise in the matters that come before the committee. Both audit committees and QLCCs, ${ }^{186}$ unlike the types of special committees that have developed under state corporate law to respond to a specific transaction or event, ${ }^{187}$ are intended to divide the board's responsibilities by a permanent partitioning of the board of directors. Both focus the compliance functions of the board of directors within a subset of the directors. Finally, both audit committees and QLCCs are empowered to retain their own professional advisors and to make decisions on behalf of issuers without the acquiescence of either the full board of directors or management. ${ }^{188}$

Concededly, the analogy between audit committees and QLCCs is imperfect. In particular, the audit committee is designed to conduct regularized activities in conjunction with management. The regular nature of the committee's work is likely to lead the committee, over time, to develop knowledge of the issuer that increases the committee's effectiveness. This knowledge may be increased by management's participation in audit committee functioning. In addition, members of the audit committee are required to have financial expertise-a type of specialization that facilitates the committee's role in overseeing the issuer's financial reporting.

186. To some extent, these observations may also apply to compensation and nominating committees. Pending regulatory reforms are likely to increase the role and responsibilities of compensation and nominating committees and to bring those committees further in line with the analysis of audit committees contained in this Article. See, e.g., Disclosure Regarding Nominating Committee Functions and Communications Between Security Holders and Boards of Directors, Exchange Act Release No. 48,301, 68 Fed. Reg. 48,724 (Aug. 14, 2003) (proposing new disclosure requirements aimed at increasing transparency of nominating committee processes); Self-Regulatory Organizations; Notice of Filing of Proposed Rule Change and Amendment No. 1 Thereto by the New York Stock Exchange, Inc. Relating to Corporate Governance, Exchange Act Release No. 47,672, 68 Fed. Reg. 19,051, 19,054 (Apr. 17, 2003) (proposing rules requiring listed companies to have nominating and compensation committees comprised entirely of independent directors).

187. Issuers have increasingly used special board committees in connection with a specific transaction to remove the taint of conflicts of interest. These temporary committees may, for example, be used in negotiating management buyouts, in reviewing shareholder derivative litigation, and in approving conflict of interest transactions. See, e.g., Kahn v. Lynch Communication Sys., Inc., 638 A.2d 1110, 1113 (Del. 1994) (describing the use of an independent committee to negotiate the proposed transaction between the issuer and its controlling shareholder); Carlton Invs. v. TLC Beatrice Int'l Holdings, Inc., No. 13,950, 1997 Del. Ch. LEXIS 86, at *26-41 (Del. Ch. May 30, 1997) (describing role of special litigation committee in negotiating settlement of shareholder derivative litigation).

188. See 17 C.F.R. $\$ 205.2(\mathrm{k})(3)(\mathrm{ii})$ (C) (2003) (requiring that the QLCC have the authority to retain the expert personnel the committee deems necessary). 
In contrast, the QLCC's work in responding to reports of misconduct is likely to occur on an episodic basis. Specific reports of misconduct need not be related to each other, and may not, over time, increase the effectiveness of the committee. Moreover, management is explicitly excluded from the work of the QLCC. Thus, unlike the audit committee, the QLCC cannot be used to channel information from management and the auditors to the full board of directors. Finally, Rule 205 does not require members of the QLCC to possess any specific qualifications, although legal training, in particular, might facilitate the QLCC's ability to evaluate the likelihood of misconduct and to identify an appropriate response.

To the extent that these differences are significant, they suggest that any lessons from the audit committee experience be evaluated cautiously. In particular, they might suggest that QLCCs will be less effective than audit committees. Nonetheless, the similarities between audit committees and QLCCs, and the absence of any direct experience with QLCCs, suggest that audit committees can provide useful information for predicting the performance of QLCCs. As we next show, empirical evidence regarding the audit committee experience provides some support for the premise that specialist board committees can improve issuer monitoring. Nevertheless, the audit committee experience also identifies a key limitation in the Commission's approach-its failure to provide adequate incentives for active and informed director involvement in corporate decisionmaking.

3. The Effectiveness of Audit Committees. The Commission's initiatives regarding audit committees have drawn mixed reviews. Anecdotal evidence suggests that the audit committee requirements elevate form over substance and do little to increase the effectiveness of the board of directors. Audit committee members often remain beholden to the chief executive officer, making them reluctant to challenge the executive's authority. As long ago as 1977, Commission Chairman Roderick Hills noted that, while members of a board of directors or audit committee may satisfy objective criteria regarding independence from management, in many instances the election of 
these directors to the board and the committee is influenced by the chief executive officer of the issuer. ${ }^{189}$

More recently, comments by both audit committee members and chief executive officers reflect doubt concerning the true independence of even nominally independent directors. For example, Robert Jaedicke, the chairman of the audit committee at Enron, described his role on the committee as "[t]o support management." And, following the collapse of Waste Management, the new chairman remarked that, as a general matter, chief executive officers are too often successful in their efforts to ensure that members of audit committees are "willing to go along with the flow-and not rock the boat." 191

A fundamental premise of the Commission's governance model, with its focus on board and committee independence, is that independent directors will be active and effective monitors. ${ }^{192}$ Even if directors are truly independent of management, questions remain concerning the effectiveness of the monitoring model of the board of

189. See Joel Seligman, No One Can Serve Two Masters: Corporate and Securities Law After Enron, 80 WASH. U. L. Q. 449, 494 (2002) (describing the history of concerns regarding audit committee effectiveness). For a review of the psychological underpinnings of directors' lack of actual independence from management, see James D. Cox \& Harry L. Munsinger, Bias in the Boardroom: Psychological Foundations and Implications of Corporate Cohesion, 48 LAW \& CONTEMP. PROBS. 83 (Fall/Winter 1985). See also Fisch, supra note 144, at 270 ("Many nonemployee directors have substantial professional or personal ties to the [issuer] or its [chief executive officer]. These ties may interfere with a director's ability to monitor aggressively due to fears of retaliation by the [chief executive officer]." (footnote omitted)).

190. Marie Brenner, The Enron Wars, VANITY FAIR, Apr. 2002, available at http://mariebrenner.com/articles/enron/en4.html (on file with the Duke Law Journal).

191. Joann S. Lublin \& Elizabeth MacDonald, Management: Scandals Signal Laxity of Audit Panels, WALL ST. J., July 17, 1998, at B1.

192. See Listed Company Audit Committee Release, supra note 65, at 87,407-14 (adopting heightened standards of independence for members of audit committees). 
directors. ${ }^{193}$ The monitoring model may sacrifice other components of board value. ${ }^{194}$ Independence, moreover, is not an unqualified benefit. Although independent directors may lack disabling conflicts of interest, they may also lack sufficient focus and involvement regarding the affairs of the issuers they serve. ${ }^{195}$

The mix of advantages and disadvantages associated with independent directors may explain the ambiguous empirical evidence regarding their effectiveness. Empirical studies have failed to find convincing evidence that greater board independence leads to improved corporate performance. ${ }^{196}$ Although some studies have demonstrated a relationship between board independence and monitoring, they have failed to demonstrate a link between

193. See, e.g., Fisch, supra note 144, at 268-75 (describing the support for the model of the monitoring board and contrasting the model with that of the managing board); Gregory S. Rowland, Earnings Management, the SEC, and Corporate Governance: Director Liability Arising from the Audit Committee Report, 102 Colum. L. REV. 168, 186 (2002) (noting "the growing implementation of the monitoring board in practice and statute, and the increasing emphasis the courts and the [Commission] place on the concept"). Only independent directors, of course, may reasonably be expected to perform effective monitoring functions, as directors who are not independent from management are, by definition, members of management (or very closely associated with management). See Larry E. Ribstein, Market vs. Regulatory Responses to Corporate Fraud: A Critique of the Sarbanes-Oxley Act of 2002, 28 J. CORP. L. 1, 11 (2002) ("Independent directors who do not work full-time for the corporation . . . theoretically are in a position to watch over [management].").

194. See Langevoort, supra note 132, at 800 ("Too much true independence in the boardroom has unintended consequences: By reducing the level of trust that comes from closer or less adversarial relationships, it chills communication, leads to a variety of influence activities by insiders, and produces more complicated (and less useful) agendas and debates."); see also Fisch, supra note 144, at 272 ("Board function need not be viewed solely in terms of monitoring management.").

195. As Professor Bill Bratton observes, "the degree of attention and quality of judgment actually brought to bear" on any matter by independent (or any other) directors can not be mandated. William W. Bratton, Does Corporate Law Protect the Interests of Shareholders and Other Stakeholders?: Enron and the Dark Side of Shareholder Value, 76 TUL. L. REV. 1275, 1334 (2002).

196. See Fisch, supra note 144, at 277 ("[S]tudies have failed to establish an empirical link between board independence and profitability."); Benjamin E. Hermalin \& Michael S. Weisbach, Boards of Directors as an Endogenously Determined Institution: A Survey of the Economic Literature, FeD. ReS. BANK N.Y. ECON. POL'Y REV., Apr. 2003, at 7, 12 (“Overall, there is little to suggest that board composition has any cross-sectional relationship to firm performance." (footnote omitted)). But see Laura Lin, The Effectiveness of Outside Directors as a Corporate Governance Mechanism: Theories and Evidence, 90 Nw. U. L. REV. 898, 922 (1996) ("Four studies have found some evidence indicating a positive relation between presence of outside directors and financial performance of the firm."). 
monitoring and performance. ${ }^{197}$ Indeed, the first large-sample, longhorizon study of the impact of board independence on issuer performance, conducted by Professors Sanjai Bhagat and Bernard Black, concludes that more independence does not result in better performance. ${ }^{198}$ Furthermore, earlier work of Professors Bhagat and Black suggests "the opposite-that [issuers] with supermajorityindependent boards perform worse than other [issuers], and that [issuers] with more inside than independent directors perform about as well as [issuers] with majority (but not supermajority) independent boards." $" 199$

Empirical studies, of course, have significant limitations. As Professors Bhagat and Black and other researchers studying the impact of board independence on performance recognize, it is difficult to measure the extent to which directors are actually independent from the management of the companies they serve. ${ }^{200}$ Professor Donald Langevoort cogently describes the difficulty in this way:

"Independence" is a subjective concept that connotes a willingness to bring a high degree of rigor and skeptical objectivity to the evaluation of company management and its plans and proposals. However, these studies have to use rough proxies for independence; the simple absence of a job with the company, a lack of a close family connection, or (perhaps) the absence of a regular stream of income from the company apart from directors' fees and dividends are all that it takes to qualify. Under these restrictive definitions, many directors who lack any real desire to take their monitoring role seriously—who are on the board for reasons of status-seeking,

197. See, e.g., Mark S. Beasley, An Empirical Analysis of the Relation Between the Board of Director Composition and Financial Statement Fraud, 71 ACCT. REV. 443, 445 (1996) (showing that issuers with more independent boards experience fewer instances of financial statement fraud); Michael S. Weisbach, Outside Directors and CEO Turnover, 20 FIN. ECON. 431, 457 (1988) (citing study results "consistent with the hypothesis that outside boards improve firm value by replacing bad management" more often than inside boards).

198. Sanjai Bhagat \& Bernard S. Black, The Non-Correlation between Board Independence and Long-Term Firm Performance, 27 IOWA J. CORP. L. 231, 248-60 (2002).

199. Sanjai Bhagat \& Bernard S. Black, The Uncertain Relationship between Board Composition and Firm Performance, 54 Bus. LAW. 921, 921-22 (1999).

200. Bhagat \& Black, supra note 198, at 266-67. 
sociability, or the perquisites that come with board membershipfall into the "independent" category, thereby muddying the data. ${ }^{201}$

In addition, corporate performance is a function of many factors, creating challenges for researchers seeking to measure the relationship between any single factor and performance. ${ }^{202}$

Despite these challenges, empirical studies focused specifically on audit committees may provide some guidance in assessing the potential value of the QLCC. On this issue, the empirical evidence is at odds with recent anecdotal evidence of audit committee failures. In particular, studies have demonstrated a correlation between audit committee independence and improved audit committee functioning. ${ }^{203}$ For example, researchers have found that: (1) the independence of audit committees "is positively related to the informativeness of accounting data in valuation" exercises; ${ }^{204}$ (2) issuers that demand greater certification from their auditors are most likely to have completely independent (and active) audit committees ${ }^{205}(3)$ audit committees comprised of more independent directors (and with greater governance expertise and lower shareholdings) "are more effective in shielding auditors from dismissal" following the issuance of a "going-concern" report; ${ }^{206}(4)$ audit committees comprised of independent directors with greater experience and greater audit knowledge are associated with greater support for auditors who advocate a "substance over form" approach

201. Langevoort, supra note 132, at 798-99 (footnotes omitted); see also Fisch, supra note 144 , at 279 ("Defining independence appropriately for purposes of these studies is particularly difficult.").

202. See Hermalin \& Weisbach, supra note 196, at 12 (discussing problems in measuring the relationship).

203. But see Andrew J. Felo et al., Audit Committee Characteristics and the Perceived Quality of Financial Reporting: An Empirical Analysis 25 (June 24, 2003) (unpublished manuscript, on file with the Duke Law Journal) (finding evidence that audit committee independence is not related to financial statement quality).

204. April Klein, Causes and Consequences of Variations in Audit Committee Composition 27 (New York Univ. Ctr. for Law \& Bus., Working Paper No. CLB-00-002, 2000), available at http://www.stern.nyu.edu/clb/00-002.pdf (last visited Sept. 26, 2003) (on file with the Duke Law Journal).

205. Dan N. Deli \& Stuart L. Gillan, On the Demand for Independent and Active Audit Committees, 6 J. CORP. FIN. 427, 428 (2000).

206. Joseph V. Carcello \& Terry L. Neal, Audit Committee Characteristics and Auditor Dismissals Following “New” Going-Concern Reports, ACCT. REV., Jan. 2003, at 95, 95. 
in disputes with management; ${ }^{207}$ and (5) audit committee members who are managers of other issuers (and so are independent and wellversed in current accounting and reporting standards) are more likely to support auditors in disputes with management than are audit committee members who are retired managers or who are individuals without significant business experience..$^{208}$ These findings lend some of the strongest support to the Commission's approach to corporate governance in general, and to the Commission's audit committee initiatives in particular.

The most substantial limitation of these studies is their failure to demonstrate a relationship between audit committee independence and the accuracy of an issuer's financial reporting. Recall that the dominant corporate governance problem triggering the adoption of Sarbanes-Oxley was the inaccuracy of publicly reported accounting information. Empirical work addressing this question is more limited and less convincing.

In a recent study, Professor April Klein considered the relationship between audit committee independence and earnings management, and she found a negative (nonlinear) relationship between audit committee independence and earnings manipulation. ${ }^{209}$ Importantly, however, Professor Klein found a significant relationship only in circumstances in which less than a majority of the committee members were independent directors. ${ }^{210}$ For restatements of financial statements, although one recent study found a significant and negative association between the independence of audit committee members and the occurrence of financial reporting

207. F. Todd DeZoort \& Steven E. Salterio, The Effects of Corporate Governance Experience and Financial Reporting and Audit Knowledge on Audit Committee Members' Judgments, 20 Auditing: J. PRAC. \& THEORY 31, 43 (2001).

208. Michael C. Knapp, An Empirical Study of Audit Committee Support for Auditors Involved in Technical Disputes with Client Management, 62 ACCT. REV. 578, 579-80 (1987).

209. Professor Klein examined the relation between the proportion of independent directors on an audit committee and abnormal accruals, which are considered proxies for earnings management. April Klein, Audit Committee, Board of Director Characteristics, and Earnings Management, 33 J. ACCT. \& ECON. 375, 376-77 (2002). In studying only current accruals (on the theory that current accruals may more easily be manipulated by management than longterm accruals), several researchers found no relation between (current) accruals and the proportion of independent directors on the audit committees of the issuers in their sample. Biao Xie et al., Earnings Management and Corporate Governance: The Role of the Board and the Audit Committee, 9 J. CORP. Fin. 295, 307 (2003).

210. Klein, supra note 209, at 376-77. 
restatements, ${ }^{211}$ another found a negative relationship between the characteristics of audit committee members and the probability of a restatement of earnings only when audit committee members were not only independent, but also financial experts. ${ }^{212}$ In analyzing the impact of independent directors and financial experts on earnings restatements, the use of multiple regression analysis revealed that the presence on an audit committee of an independent director with financial expertise is negatively correlated with restatements and significant, indicating that the selection of one director with financial expertise may offer more protection against restatements than an audit committee comprised of only independent directors. ${ }^{213}$

These results, too, have their limitations. As is the case with studies of the effectiveness of board independence, it is difficult to measure the independence of audit committee members accurately. More problematically, to the extent the studies involve periods in which the use of audit committees was not mandatory, the relationship between audit committee independence and audit committee effectiveness may be spurious. Issuers that are well run, and so have a limited need for monitoring on the part of audit committees, may create independent audit committees simply because they are well run. These issuers may also create independent audit committees as a means of signaling to investors and the capital markets their quality. In either case, evidence of a positive relationship between audit committee independence and audit committee effectiveness may not indicate a causal relationship between audit committee independence and effectiveness. ${ }^{214}$ At the

211. Lawrence J. Abbott et al., Audit Committee Characteristics and Financial Misstatement: A Study of the Efficacy of Certain Blue Ribbon Committee Recommendations 3 (Sept. 24, 2002) (unpublished manuscript, on file with the Duke Law Journal).

212. Anup Agrawal \& Sahiba Chadha, Corporate Governance and Accounting Scandals 19 (July 2003) (unpublished manuscript, on file with the Duke Law Journal). Professors Agrawal and Chadha note that, for all issuers in their sample (those that did restate earnings and those that did not), the proportion of independent directors on the audit committees was, on average, the same: approximately $71 \%$. Id. at 16 .

213. Id. at $19-20$.

214. Professors Agrawal and Chadha seek to test whether issuers that are well run are more likely than other issuers to appoint independent directors with financial expertise to their boards of directors. They examine whether or not operating performance varies across the issuers in their sample, dividing the sample into those issuers that restate earnings and those that do not restate earnings. Professors Agrawal and Chadha find that performance is not significantly related to the presence of independent directors with financial expertise, and they conclude that the presence of these directors leads to an absence of restatements. Id. at 22-23. 
end of the day, the existing empirical research provides, at best, limited support for the Commission's approach.

More importantly, precisely because the empirical studies do not measure the relationship between regulatory changes and audit committee functioning, they cannot capture the effectiveness of the rule-based approach. The studies do not answer the question of whether mandated reforms to board structure or composition address underlying problems of director passivity or cronyism.

Notably, the limitations of the rule-based approach are reflected in the recent events at Enron. During the time when Enron was engaged in massive financial and reporting fraud, Enron's board of directors and audit committee were comprised of a majority of directors who were (at least nominally) independent from Enron's officers. ${ }^{215}$ As one commentator observed, "Enron had a fully functional audit committee operating under the [Commission]'s expanded rules on audit committee disclosure." ${ }^{216}$ In terms of structure, if not performance, Enron's audit committee met or exceeded existing corporate governance standards such as those of the Blue Ribbon Panel. ${ }^{217}$ Indeed, Enron's audit committee was chaired by Robert K. Jaedicke, dean and a professor of accounting at Stanford University School of Business. ${ }^{218}$

Many commentators have rightly questioned whether or not the members of Enron's board of directors and audit committee were

215. See, e.g., Erica Beecher-Monas, Corporate Governance in the Wake of Enron: An Examination of the Audit Committee Solution to Corporate Fraud, 55 ADMIN. L. REV. 357, 359, 364 (2003) (describing Enron's audit committee as consisting of "six independent directors, two of whom had formal accounting training and experience, and only one who was less than expert").

216. Ribstein, supra note 193 , at 26.

217. See generally Report and Recommendations of the Blue Ribbon Committee on Improving the Effectiveness of Corporate Audit Committees, available at http://www.nyse.com/pdfs/blueribb.pdf (Feb. 8, 1999) (on file with the Duke Law Journal) (setting forth recommendations aimed at increasing the independence, effectiveness, and accountability of audit committees).

218. Douglas M. Branson, Enron-When All Systems Fail: Creative Destruction or Roadmap to Corporate Governance Reform?, 48 VILL. L. REV. 989, 1016 (2003). 
actually independent from management. ${ }^{219}$ It is likely, however, that the difficulties with the board of directors and the audit committee stemmed not from structural problems but rather from the directors' failure to remain informed and to oversee closely the transactions in which management engaged. ${ }^{220}$ As Professor Janis Sarra has observed, although all but two of Enron's fifteen directors "were ostensibly independent," the "board culture ... was unquestioning" and so did not "provide for healthy scrutiny and monitoring of the corporate officers." 221 This leads Professor Sarra to conclude that the presence of "'independent directors' is in itself insufficient guarantee of independent oversight."222 Professor Sarra further notes that "[t]he Powers Report [prepared by the Special Investigative Committee of the Board of Directors of Enron] also found that the [a]udit [c]ommittee... consisted of independent directors, but that they failed to investigate or give serious consideration to the related party transactions."

A final question remains: is the Commission's rule-based approach to the board of directors and its functions likely to lead to effective monitoring of corporate decisionmaking? The experience with audit committees offers reasons to question the value of corporate governance structures, such as specialized board committees, unless these structures provide adequate incentives for active and informed decisionmaking. As Bill Lerach has observed, "in truth, audit committees have provided little protection against

219. See, e.g., Fisch \& Rosen, supra note 16, at 1120-21 (citing to various authorities identifying conflicts, biases, and relationships that potentially compromised the judgment of the Enron directors); Jeffrey N. Gordon, What Enron Means for the Management and Control of the Modern Business Corporation: Some Initial Reflections, 69 U. CHI. L. REV. 1233, 1241-42 (2002) ("[T]he independence of virtually every board member, including [a]udit [c]ommittee members, was undermined by side payments of one kind or another. Independence also was compromised by the bonds of long service and familiarity." (footnote omitted)); Joanne S. Lublin, Inside, Outside Enron, Audit Committee Is Scrutinized, WALl ST. J., Feb. 1, 2002, at C1 (identifying audit committee conflicts of interest).

220. See, e.g., Bratton, supra note 195, at 1334 (warning that a structural approach to good governance may result in boards of directors that simply go through the motions because the approach "cannot make the further subjective inquiry into the degree of attention and quality of judgment actually brought to bear").

221. Janis Sarra, Rose-Colored Glasses, Opaque Financial Reporting, and Investor Blues: Enron as Con and the Vulnerability of Canadian Corporate Law, 76 ST. JOHN's L. REV. 715, 728 (2002).

222. Id.

223. Id. (citing Powers et al., supra note 1). 
financial manipulation." ${ }^{224}$ The Wall Street Journal has described audit committees as "toothless tigers." 225 Accordingly, in Part III, we consider several alternative ways to increase the incentives for directors to monitor management decisions.

\section{CREATING InCENTIVES FOR DiRECTOR ACTIVISM}

Part II highlights the shortcomings of the Commission's approach to corporate governance reform. Most problematically, recent corporate governance scandals have revealed a troubling degree of director passivity. ${ }^{226}$ As Ira Millstein recently observed, "in many of the recent highly public corporate governance failures, a more active, engaged, and informed board of directors might have uncovered, prevented, or at least mitigated the crisis that caused many of these companies to collapse., ${ }^{227}$

The Commission's proposed solution, a rule-based approach to board structure with increased emphasis on specialized board committees comprised of independent directors, is unlikely to address the problem of director passivity. ${ }^{228}$ Importantly, directors continue to face a conflict between maintaining their loyalty to management and challenging management's decisions. ${ }^{229}$ Directors continue to be

224. William S. Lerach, Plundering America: How American Investors Got Taken for Trillions by Corporate Insiders-The Rise of the New Corporate Kleptocracy, 8 STAN. J.L. BUS. \& FIN. 69, 106 (2002).

225. Lublin \& MacDonald, supra note 191.

226. See, e.g., Marleen A. O'Connor, The Enron Board: The Perils of Groupthink, 71 U. CINN. L. REV. 1233, 1234-35 (describing director passivity at Enron); Sarra, supra note 221, at 728 (same); Floyd Norris, Ebbers and Passive Board Blamed for Worldcom Woes, N.Y. TIMES, June 10, 2003, at C1 (describing two reports finding director passivity at Worldcom); Ira Millstein, A Self-Correcting Course for Governance, DIRECTORS \& BOARDS, Spring 2003, at 26, 27 (observing that director passivity appears to have been "more prevalent than many believed").

227. Millstein, supra note 226, at 27.

228. One might argue that the creation of a QLCC could be valuable by modifying the norms applicable to director conduct, even in the absence of an increased liability risk or direct financial incentives to motivate QLCC members. Although the "norms" literature has become increasingly important in corporate law, see, e.g., Symposium, Norms and Corporate Law, 149 U. PA. L. REV. 1607 (2001) (debating the role of norms in various corporate law contexts), we argue that structural requirements such as greater director independence and the establishment of more board committees have not had the effect of modifying the "norm" of director passivity and are unlikely to do so. See Millstein, supra note 226, at 27-28 (recognizing the need for further regulatory changes to increase meaningful levels of director oversight).

229. See, e.g., Martin Lipton, The Millennium Bubble and Its Aftermath: Reforming Corporate America and Getting Back to Business, M\&A LAWYER, July-Aug. 2003, at 1, 1 (observing that "'independent' directors often were independent in name but not in spirit"). 
limited in the time and expertise that they are able to bring to monitoring management. ${ }^{230}$ Most importantly, directors continue to rely on the combination of superficial compliance with reporting, record-keeping, and other procedural requirements, and the delegation of discretionary decisionmaking to outside experts, to satisfy their obligations. So long as adherence to procedural standards, coupled with the retention of outside professionals, is sufficient to insulate directors from personal accountability, there is little reason to expect directors to monitor management closely. Instead, the proliferation of board committees and the creation of specialist directors will simply increase the costs of corporate governance.

How can this culture be changed? Although a complete development of the appropriate framework is beyond the scope of this Article, we briefly consider three alternative mechanisms for increasing director incentives to monitor effectively. We first consider increased director liability. We then examine changes to director compensation. Finally, we consider alternative director selection procedures.

\section{A. Increased Director Liability}

Clearly, the prospect of significant personal liability for corporate failures would create strong incentives for directors to monitor management closely. Initially, it might seem that directors already face the prospect of personal liability for failure to exercise sufficient oversight. The obligation to monitor management, and to oversee the issuer's system of internal controls, is a central component of the fiduciary duties directors owe to the issuer and its shareholders. As Chancellor Allen observed in Caremark, the director's duty of care includes the role of oversight, which includes a duty to ensure that appropriate "information and reporting systems" exist to provide the board of directors with timely, accurate, and

230. See, e.g., David S. Hilzenrath, 'The Company's Directors were all too often a Passive Rubber Stamp for Management and Especially Mr. Ebbers.'; How a Distinguished Roster of Board Members Failed to Detect Company's Problems, WASH. Post, June 16, 2003, at E1 (quoting investigatory report of Worldcom as stating that audit committee members "devoted strikingly little time to their role, meeting as little as three to five hours per year"). 
adequate information to assess corporate compliance with legal requirements. ${ }^{231}$

As a practical matter, however, directors face limited meaningful exposure to liability. In cases of state law claims for breach of fiduciary duty, director exculpation clauses, procedural impediments to derivative litigation, and liability insurance make the prospect of personal liability for directors remote. With respect to federal law, limitations on the exposure of secondary actors-including the decision in Central Bank $k^{232}$ and the reforms of the Private Securities Litigation Reform $\mathrm{Act}^{233}$-limit the ability of plaintiffs to proceed against independent directors for securities fraud. With the noted exception of Smith v. Van Gorkom, ${ }^{234}$ there are virtually no cases in which independent directors have been held personally liable, under state or federal law, absent an active role in, or actual knowledge of, corporate wrongdoing.

The newly developing role of the specialist director may mean that the directors who perform this role, such as members of audit committees and QLCCs, will be subject to an increased risk of liability. Consider the risk of liability for audit committee members. With the recent volume of accounting scandals, the role of the audit committee has received substantial attention. Many commentators have warned that audit committee members are more likely than other directors to be sued. ${ }^{235}$ The extent to which audit committee

231. In re Caremark Int'1 Inc. Derivative Litig., 698 A.2d 959, 968-70 (Del. Ch. 1996); see also Colloquium, Corporate Law in the Twenty-First Century: The Practitioners' Prognosis, 25 DEL. J. CORP. L. 161, 174-75 (2000) (practitioners Arthur Fleischer, Jr. \& Peter A. Atkins, presenting) ("When addressing the board's oversight function, some question may exist whether directors are exercising business judgment of the type protected by the business judgment rule.").

232. Central Bank of Denver v. First Interstate Bank of Denver, 511 U.S. 164, 191 (1994) (holding that Rule 10b-5 does not include a private right of action for aiding and abetting federal securities fraud).

233. Private Securities Litigation Reform Act of 1995, Pub. L. No. 104-67, 109 Stat. 737 (codified in scattered sections of 15 U.S.C.).

234. 488 A.2d 858 (Del. 1985). In Smith v. Van Gorkom, the Delaware Supreme Court held that the directors were grossly negligent in approving the sale of the company without informing themselves of the relevant considerations. Id. at 874.

235. See, e.g., Ira M. Millstein, Introduction to the Report and Recommendations of the Blue Ribbon Committee on Improving the Effectiveness of Corporate Audit Committees, 54 Bus. LAW. 1057, 1064 (1999) (discussing concern that the recommendations of the Blue Ribbon Committee on Improving the Effectiveness of Corporate Audit Committees may expose audit committee members to "increased risk of class action and derivative lawsuits, if not increased liability"); John F. Olson et al., After Enron: Issues for Boards and Audit Committees to Consider, CORP. GOVERNANCE ADVISOR, May-June 2002, at 14, 14 ("[A]udit committees no 
members will be held liable, however, and the conditions under which courts will impose liability, remain uncertain. ${ }^{236}$ Despite the long history of the use of audit committees and the increasing expansion of the audit committee's role and responsibilities, the scope of committee member obligations under existing law is poorly defined.

With respect to state law, some commentators have argued that, under Delaware law, the obligations of audit committee members are simply the traditional duties of care and of loyalty, and the legal standards for assessing audit committee member conduct do not differ from those applicable to other directors. ${ }^{237}$ In particular, unless the directors have "either abdicated their functions, or absent a conscious decision, failed to act," decisions made by directors are protected by the business judgment rule. ${ }^{238}$

Similarly, in several federal securities fraud cases, the courts have declined to impose liability on audit committee members based solely on their membership on the committee. Most notably, in Livent Securities,${ }^{239}$ the court dismissed as insufficient a complaint alleging liability of the audit committee members based either on their

doubt will face greater scrutiny in the post-Enron environment ...."). Rules relating to audit committees and the consequent liability exposure of audit committee members continue to evolve as new corporate governance reforms are implemented.

236. See, e.g., Kevin Iurato, Comment, Warning! A Position on the Audit Committee Could Mean Greater Exposure to Liability: The Problems with Applying a Heightened Standard of Care to the Corporate Audit Committee, 30 STETSON L. REv. 977, 987 (2001) ("A review of these cases reveals little guidance about the direction in which the courts are headed on the issue of audit committee member liability . ..."); Olson et al., supra note 235, at 19 n.1 (“[A] long history of judicial authority and the practical implications of a heightened standard in deterring board service by qualified individuals militate strongly against any radical revision of the liability standard applicable to directors.").

237. See, e.g., Olson et al., supra note 235, at 14 ("Similar to other directors, audit committee members have two basic duties: care and loyalty."); see also In re Abbott Labs. Derivative S'holders Litig., 325 F.3d 795, 803-09 (7th Cir. 2003) (applying Illinois law and holding all directors, including audit committee members, to same standards of care, loyalty, and good faith in determining futility of demand in derivative suit).

238. Aronson v. Lewis, 473 A.2d 805, 813 (Del. 1984), overruled on other grounds by Brehm v. Eisner, 746 A.2d 244 (Del. 2000). In a recent challenge to the approval of an executive compensation contract, the Delaware Court of Chancery held all directors-including members of the compensation committee - to the same standard in concluding that the complaint alleged facts sufficient to allow the court to determine that the directors, in consciously and intentionally disregarding their responsibilities, breached their duty of good faith and that their conduct fell outside the protections of the business judgment rule. In re Walt Disney Co. Derivative Litig., 825 A.2d 275, 287-90 (Del. Ch. 2003).

239. In re Livent, Inc. Sec. Litig., 148 F. Supp. 2d 331 (S.D.N.Y. 2001). 
positions or on the existence of "red flags"-accounting violationsthat the committee ignored or failed to investigate. ${ }^{240}$

In other cases, however, the federal courts have suggested, at least for purposes of the early stages of the litigation, that audit committee members may be held to a different legal standard than other independent directors. These decisions rely upon the superior access by audit committee members to internal financial information and the heightened responsibility audit committee members have to monitor the auditing process. ${ }^{241}$ Importantly, however, despite the expansive language in some of these cases, we have uncovered no reported decisions imposing liability on members of an audit committee who were not otherwise involved in the misconduct. Thus, despite the critical role of the audit committee in monitoring management, audit committee members do not currently appear to face meaningful liability exposure for failure to exercise sufficient oversight. ${ }^{242}$

The Commission itself has vacillated as to the impact of audit committee membership on the liability exposure of member directors.

240. Id. at 371-73; see also In re Oak Tech. Sec. Litig., No. 96-20552 SW, 1997 WL 448168, at *11 (N.D. Cal. Aug. 1, 1997) (concluding that allegations that audit committee members merely held positions on the committee are insufficient to set forth circumstances constituting fraud with particularity); Haltman v. Aura Sys., Inc., 844 F. Supp. 544, 549 (C.D. Cal. 1993) (stressing that director's status as a member of the audit committee, "in and of itself, is insufficient to link [the director] to the alleged fraud").

241. See, e.g., AUSA Life Ins. Co. v. Dwyer (In re JWP Inc. Sec. Litig.), 928 F. Supp. 1239, 1259-61 (S.D.N.Y. 1996) (denying a motion for summary judgment by audit committee defendants accused of being "willfully blind" in their supervision of a fraudulent auditor); In re MTC Elec. Techs. S'holders Litig., 898 F. Supp. 974, 979-80 (E.D.N.Y. 1995) (denying dismissal motions of defendant members of audit committee on the ground that, because they were charged with overseeing the auditors, allegations of accounting fraud were sufficiently particular to them), vacated in part, 993 F. Supp. 160 (E.D.N.Y. 1997); Tischler v. Baltimore Bancorp, 801 F. Supp. 1493, 1500-01 (D. Md. 1992) (denying dismissal motions of defendant members of audit committee on ground that, because members had inside knowledge of issuer's financial status, they were required to question information alleged to be inconsistent with other information available to them); Greenfield v. Prof'l Care, Inc., 677 F. Supp. 110, 114-15 (E.D.N.Y. 1987) (denying dismissal motions for defendant members of audit committee because allegations of actual knowledge of, or reckless disregard for, fraud caused members to appear more like "inside" directors than independent directors); Dubowski v. Ash (In re AM Int'l Inc. Sec. Litig.), 606 F. Supp. 600, 605 (S.D.N.Y. 1985) (denying dismissal motions for defendant members of the audit committee because their access to issuer information and their responsibility for reviewing the audit were sufficient to hold them to the same standard as management directors).

242. See, e.g., Hilzenrath, supra note 230 (quoting Thornburgh Report's observation that "over the years, the [Worldcom] audit committee "barely scratched the surface of any potential accounting or financial reporting issues"”). 
On the one hand, the Commission has assured issuers that audit committee membership does not increase liability exposure. ${ }^{243}$ Indeed, the Commission adopted an affirmative safe harbor in connection with its recent rules increasing the required disclosure regarding audit committees and the committee members designated as financial experts. The safe harbor explicitly provides that designation or identification of a person as a financial expert under the new disclosure rules cannot be used as a basis for imposing private civil liability on audit committee members. ${ }^{24}$ On the other hand, Commission Director of Enforcement Stephen Cutler has warned issuers " $[\mathrm{t}]$ here is no accounting or financial reporting case that we are investigating in which we don't closely scrutinize the conduct of the board of directors, including outside directors." 245

The current uncertainty is troubling for two reasons. First, in the face of uncertainty, committee members are likely either to underestimate or to overestimate their potential liability. ${ }^{246}$ To the extent committee members underestimate their potential liability, the effectiveness of legal standards establishing these committees and setting forth their obligations is reduced. If committee members view themselves as facing little meaningful exposure to liability for failing to monitor actively, they will have little incentive to question management or auditors or to challenge management's recommended course of action. In short, underestimations of director liability exposure compound the problem of director passivity. In contrast, directors who overestimate the risk of liability are unlikely to serve as members of specialist committees or perhaps even as board members.

243. See Audit Committee Disclosure, Exchange Act Release No. 42,266, 64 Fed. Reg. $73,389,73,391$ (Dec. 30, 1999) ("It is not our intention to subject audit committee members to increased liability.").

244. Disclosure Required by sections 404, 406 and 407 of the Sarbanes-Oxley Act of 2002, Exchange Act Release No. 47,235, [2002-2003 Transfer Binder] Fed. Sec. L. Rep. (CCH) II 86,818 , at 86,894 (Jan. 23,2003 ) ("Our new rule provides that whether a person is, or is not, an audit committee financial expert does not alter his or her duties, obligations or liabilities. We believe this should be the case under federal and state law.").

245. Stephen Taub, Homestore on the Range, CFO.com, at http://www.cfo.com/ Article? article $=7760$ (Sept. 26, 2002) (on file with the Duke Law Journal).

246. Compare Kevin P. Kennedy \& Deanna J. Chechile, Waiting for Enforcement: How to Manage Risks for the Audit Committee in the Post-Enron World, THE SEC. REPORTER, Summer 2002, at 9, 11 (arguing that audit committee members face greater exposure both to suit and to potential liability from claims based in the federal securities laws, including disclosure regulations and antifraud provisions, in the post-Enron environment), with Rowland, supra note 193, at 207 (describing extent of increased liability exposure for audit committee members as "insignificant" and calling for a narrowing of existing safe harbors). 
Ironically, those directors most likely to engage in active oversight may be most deterred by the risk of litigation. In this way, the uncertainty may rob boards of those directors who are most likely to provide valuable service.

Second, ambiguity about liability exposure creates ambiguity with respect to the scope of the underlying obligations. If, as the Commission's safe harbor suggests, audit committee members do not face increased liability exposure, is it realistic to expect them to play an active role? The recent emphasis by Congress and the Commission, as well as the NYSE and Nasdaq, on audit committee independence, member expertise in financial matters, and audit committee procedures indicates an expectation that audit committees will provide value to issuers. There is little reason to have an independent, qualified audit committee if that committee has no greater responsibility than simply to rubber stamp auditor conclusions. But what more is required? To what extent are audit committee members responsible for making an independent assessment of the quality of the issuer's internal controls, financial statements, and financial reports? Absent appropriate guidance, even the most conscientious directors will have trouble identifying and meeting their obligations.

A tension also exists between the notion of specialized directors and the traditional reliance of issuers on the advice of professionals regarding accounting, legal, and other matters. Longstanding state law principles explicitly protect the reliance of directors on information and opinions provided by these professionals, and the principles provide that good faith reliance is a defense to allegations of a breach of fiduciary duty. For example, in the auditing context, the liability of audit committee members is inherently limited by the fact that, under state law, audit committee members may assert their reliance on the advice and reports of the auditors as a defense to claims that they acted wrongfully. ${ }^{247}$ Reasonably extended, this principle enables audit committee members to argue that they cannot be held liable so long as the issuer's auditors approved the issuer's financial statements. The problem with this argument is that insulating audit committee members from liability so long as they rely on the issuer's auditors eviscerates the audit committee's role.

247. See, e.g., Del. CodE ANN. tit. 8, § 141(e) (2001); N.Y. BUS. CoRP. LAW § 717(a)(2) (2003). 
Accordingly, if regulators expect audit committees to operate as meaningful monitors, committee members must face liability not just when they have actual knowledge of misconduct, but also for passivity-for failures to investigate potential problems based on known risks concerning the quality of the issuer's system of internal controls or financial statements and other reports. The types of risks that implicate a duty to investigate might include evidence that management has failed to comply with requests from the auditors for information or documentation, material accounting treatments that the auditors characterize as questionable or high risk, and repeated disagreements between management and the auditors regarding appropriate accounting treatments that are resolved in favor of management. In particular, these types of risks should be viewed as a warning that reliance by the directors on the auditor's opinion is unreasonable due to the likelihood that the reliability of the auditor's opinion itself is subject to question.

Analogous principles concerning the role of liability exposure apply to QLCC members. As with audit committee members, QLCC members are specialist directors and, as such, will have extensive information regarding the affairs of the issuer. More than audit committee members, QLCC members also will have specific knowledge of potential accounting and other problems, obtained through the process of receiving and investigating reports of misconduct. Accordingly, courts will have to determine the extent to which QLCC members face greater liability exposure than nonspecialist directors. Will QLCC members be held accountable for failing to take sufficient actions to prevent, or at least limit, conduct that, with the benefit of hindsight, turns out to be illegal? Importantly, Rule 205.7 expressly disavows an intention to create a private right of action against members of the QLCC. ${ }^{248}$ If QLCC members face no threat of liability - a conclusion suggested by this language-QLCC members will have no greater incentive to investigate or respond to wrongdoing than the members of Enron's audit committee.

248. See 17 C.F.R. § 205.7 (2003) (stating that Rule 205 does not create a private right of action against attorneys, law firms, or issuers); see also Adopting Release, supra note 59, at 87,083 ("[T] he Commission does not intend service on a QLCC to increase the liability of any member of a board of directors under state law and, indeed, expressly finds that it would be inconsistent with the public interest for a court to so conclude."). 
Similarly, Rule 205 explicitly contemplates that QLCCs will routinely hire advisors, including attorneys and even forensic accountants, to investigate reports of misconduct. The natural result of this process is a professionally prepared report setting forth a "colorable defense" and concluding that no further action is required. ${ }^{249}$ If directors are entitled to rely on professional advice, then this defense would appear to shield QLCC members from all personal accountability, eliminating any incentive for them to take personal initiative with respect to the inquiry.

One might respond to these concerns by observing that the mere process of hiring independent advisors to investigate reports of misconduct is, by itself, beneficial. To a point this is true-reputable accounting firms and law firms are unlikely to whitewash egregious evidence of wrongdoing, Vinson and Elkins' investigation of the wrongdoing at Enron notwithstanding. ${ }^{250}$ Analysis of a more ambiguous case is more difficult. The legal standard adopted in Rule 205 , which protects the decision of a reporting attorney, and similarly a QLCC, to refrain from further action, is a determination by an investigating attorney retained by the QLCC that the issuer may assert a "colorable defense" in any proceeding related to the misconduct alleged in the report to the QLCC. ${ }^{251}$ This does not appear to be a substantial requirement, and it seems likely that, for most cases of misconduct - those involving disagreements about materiality or appropriate accounting treatment-the QLCC and its members will be able to obtain and to rely on such a determination by the QLCC's counsel. Moreover, nothing in the rule precludes a QLCC from consulting more than one investigating attorney in an effort to obtain a suitable opinion. In sum, then, for the QLCC to provide a meaningful check on misconduct, as with the audit committee, QLCC members are likely to require the incentive provided by meaningful exposure to personal liability for failure to act. The extent to which existing law provides such exposure remains uncertain.

249. Rule 205.3(b)(7)(ii) provides that an attorney who is retained by a QLC has no further reporting obligations if the attorney is able to assert, consistent with professional obligations, a colorable defense on behalf of the issuer in any proceeding relating to the related report of misconduct.

250. See Fisch \& Rosen, supra note 16, at 1110-11 (describing the investigation).

251. 17 C.F.R. $§ 205.3($ b)(7)(ii). 


\section{B. Changes To Director Compensation}

Personal liability for passivity on the part of specialist directors is, arguably, a second best solution. A more attractive alternative would be to create direct incentives for active monitoring. In recent years, commentators have devoted increasing attention to director compensation, arguing that it, like executive compensation, should be incentive-based, in order to align director interests with those of shareholders. ${ }^{252}$ In particular, commentators have advocated an increased emphasis on equity-based compensation and the elimination of benefits such as pensions and health insurance. ${ }^{253}$ Similarly, commentators have strongly criticized the presence of consulting contracts and other forms of "side payments" to directors. ${ }^{254}$ Proponents of equity-based compensation for directors argue that giving directors substantial stakes in the issuer on whose board of directors they serve will create incentives for the directors to take affirmative steps to increase shareholder value, including active monitoring, firing unproductive officers, and supervising executive compensation more carefully. ${ }^{25}$

252. See, e.g., Charles M. Elson, The Duty of Care, Compensation, and Stock Ownership, 63 U. CIN. L. REV. 649, 689-92 (1995) (arguing that paying directors in stock will "incentivize outside directors in the large public corporation to eschew their traditional passivity"); Jill E. Fisch, Teaching Corporate Governance Through Shareholder Litigation, 34 GA. L. REV. 745, 758-63 (2000) (describing general problems with executive compensation and outlining various regulatory responses).

253. See, e.g., Poonam Puri, Taking Stock of Taking Stock, 87 CoRnell L. Rev. 99, 144 (2001) (describing the National Association of Corporate Directors' Blue Ribbon Commission Report on Director Compensation as recommending "paying directors exclusively in cash and equity, with equity comprising a significant portion of overall director pay").

254. See, e.g., Permanent Subcomm. on Investigations of the S. Comm. ON Governmental Affairs, 107Th Cong., The Role of the BoARd of Directors in ENRON's COLLAPSE 53 (Comm. Print 2002) (testimony of Robert Campbell, retired chairman and chief executive officer of Sunoco) (explaining that consulting agreements and other financial ties compromise director independence).

255. See, e.g., Elson, supra note 252, at 689-92 (advocating compensating directors with stock); Fannie Mae Corporate Governance Guidelines, at http://www.fanniemae.com/ governance/principles/compensation.jhtml? $\mathrm{p}=$ Corporate\%20Governance (last visited Sept. 26, 2003) (on file with the Duke Law Journal) (describing director equity compensation as "designed to align director interests with stockholders' long-term value"); Stephen Fowler \& Dave Taylor, Director Compensation and Other Issues: Tips for Startups, at http://www.boardseat.com/Articles.asp?AID=13 (last visited Sept. 26, 2003) (on file with the Duke Law Journal) (explaining that, in general, "the best way to pay ... directors is with stock options" because they give directors "an incentive to help the company's stock increase in value"). 
The extent to which equity-based compensation provides appropriate incentives for director behavior remains an open question. Some recent empirical work supports the argument that this compensation structure increases the quality and quantity of director oversight and monitoring. For example, Professor Tod Perry has found that increased use of incentive-based compensation for directors is correlated with higher levels of board monitoring and, in particular, the likelihood of chief executive officer turnover following poor performance. ${ }^{256}$ On the other hand, as with executives, performance-based compensation may lead to higher overall compensation levels for directors. ${ }^{257}$ Moreover, at least one study has found both that higher director compensation is associated with firm underperformance and that a correlation exists between excessive director compensation and excessive compensation for the chief executive officer. ${ }^{258}$ This study identifies a risk of "cronyism," which is then associated with an environment of ineffective monitoring. ${ }^{259}$

Even if equity-based compensation aligns directors' incentives with those of shareholders, it imposes costs on issuers. Equity-based compensation, particularly stock options, may lead to an undue emphasis on stock price. Some commentators have questioned whether the increasing use of stock options to compensate corporate executives caused them to focus excessively on short term stock price

256. R. Tod Perry, Incentive Compensation for Outside Directors and CEO Turnover 17 (July 1999) (unpublished manuscript, on file with the Duke Law Journal); see also Rita D. Kosnik, Greenmail: A Study of Board Performance in Corporate Governance, 32 ADMIN. SCI. Q. 163, 179 (1987) (finding a negative relationship between the equity holdings of outside directors and the issuer's resistance to the payment of greenmail); Stephen H. Bryan et al., Compensation of Outside Directors: An Empirical Analysis of Economic Determinants 2 (Sept. 2000) (unpublished manuscript, on file with the Duke Law Journal) (finding that the level of stock option awards to independent directors is positively related to an issuer's growth opportunities, institutional stock holdings, and the threat of takeover).

257. This is a predictable result, stemming from the fact that performance-based compensation entails higher risk and, accordingly, directors will demand a higher overall level of pay to compensate them for the increased risk.

258. Ivan E. Brick et al., CEO Compensation, Director Compensation, and Firm Performance: Evidence of Cronyism 2-3 (May 1, 2002) (unpublished manuscript, on file with the Duke Law Journal); see also Graef Crystal, Paying Directors in Company Stock Doesn't Boost Performance Compensation: Stocks Don't Move in Relation to Directors' Ownership of Shares, Study Shows, L.A. TimES, Mar. 12, 1995, at D3 (describing study of fifteen top performing companies and fifteen poorly performing companies for the period from 1987 to 1994, and finding no significant statistical relationship between the equity holdings of the outside directors and the market price of a company's stock).

259. Brick et al., supra note 258, at 3. 
performance in the late $1990 \mathrm{~s}^{260}$ This focus, in turn, may have contributed to management decisions to manipulate financial statements in order to manage earnings. One could argue that directors-particularly the members of Enron's board of directors who were receiving generous compensation packages as a result of its high-flying stock price ${ }^{261}$-had specific incentives to avoid rocking the boat by inquiring too closely into the nature of the issuer's financial transactions. A similar concern might be raised about the Worldcom board, which seemingly paid little attention to management's decisions, perhaps because eight Worldcom board members owned at least a million shares of the company's stock. ${ }^{262}$

Indeed, regardless of its value in other areas, equity-based compensation is likely to provide particularly poor incentives for directors to identify and disclose evidence of misconduct. For directors who are members of the issuer's audit committee, and, in some instances, the QLCC, director activism is associated with challenging decisions that are designed to improve the issuer's reported financial performance. In the context of monitoring financial reporting, director activism will typically have the effect of making the issuer's reported financial condition look worse-with a predictable effect on the issuer's stock price. Consequently, to the extent that management is already responding to shareholder pressure to meet earnings estimates and maintain the issuer's stock price, equity-based compensation for the directors is likely to align the interests of directors with those of management.

260. See, e.g., ABA Task Force on Corp. Responsibility, Preliminary Report of the American Bar Association Task Force on Corporate Responsibility, 58 Bus. LAw. 189, 193 (2002) (seeking to explain the failures in corporate responsibility in the 1990s and stating that: equity-based executive compensation-particularly in the form of stock options-as a means intended to align the interests of managers and shareholders became increasingly prevalent and lucrative. There were unanticipated consequences. Executive officers were endowed with powerful personal incentives to meet near term Wall Street earnings expectations and to avoid any negative impact upon current stock market prices.

Ide, supra note 3, at 862 (describing the recent scandals and stating that stock options "give[] the executive the incentive to take actions to increase stock price in the short run"); Lerach, supra note 224, at 80 (noting that, during the late 1990s, "[e]xecutive compensation also changed. Executives now got cash bonuses only if earnings reached preset targets or the company's stock hit targeted prices. They received gigantic stock options, not to hold for the long term, but rather to exercise and sell each quarter").

261. See Fisch \& Rosen, supra note 16, at 1120 n.92 (describing compensation of Enron directors, including heavy reliance on stock options).

262. Norris, supra note 226. 
It would, of course, be possible to provide incentives for active monitoring by compensating directors based on the actual quantity and the quality of the services they provide to the issuer. For example, members of the audit committee who expend significant effort in learning and evaluating the issuer's financial condition, financial statements, and financial disclosures might receive a significant cash payment at the end of the fiscal year, perhaps based upon the number of hours devoted to audit committee activities. Members of a QLCC who conscientiously investigate and respond to evidence of misconduct might receive a similar payment. In addition, issuers might pay bonuses to members of the audit committee and the QLCC for active monitoring-measured by specified outcomes such as disclosure of controversial accounting treatments in the case of the audit committee or removal of officers found to be guilty of misconduct in the case of the QLCC.

By coupling compensation with services provided to the board and to the issuer, such payments would create incentives for active monitoring. As with equity-based compensation, however, there are corresponding costs. One cost is the expense of the payments themselves, which would have to be substantial to provide meaningful incentives given the stature and financial condition of directors of public companies. Second and more problematic is the cost of measuring the level of effort expended by the directors. In effect, the approach would entail an additional level of monitoring. Third, incentive-based payment structures may, as is sometimes reported with respect to police officers who receive bonuses for making a targeted number of arrests, produce inefficient levels of performance. Finally, directors, like other corporate executives, appear particularly sensitive to their treatment relative to their peers. Differences in the compensation paid to different directors is likely to diminish significantly the collegiality among members of the board, which, in turn, may impair board effectiveness.

\section{Alternative Director Selection Procedures}

A third mechanism for increasing director accountability is reform of the director selection process. It is common knowledge that, although shareholders nominally elect members of the board of directors, in the vast majority of cases shareholders vote on a single slate of candidates who are chosen, directly or indirectly, by management. Because shareholders do not meaningfully evaluate and choose directors, directors are not directly accountable to 
shareholders. As a result, director monitoring is unlikely to be influenced by concerns of directors about their reputation-at least their reputation among shareholders. Indeed, to the extent that reputation operates as a constraint on director behavior, directors are more likely to be concerned about their reputation for pleasing management. Directors who ask too many questions are likely to irritate management and lose their board positions.

Modifying the director selection process to incorporate greater shareholder input would increase director accountability to shareholders. Commentators have proposed various alternative methods of increasing shareholder input, ranging from direct shareholder nomination of directors to procedures that facilitate shareholder participation in the selection process. ${ }^{263}$ Each of these proposals would enable shareholders to participate more actively in the selection of directors, which would, in turn, increase director incentives to act in the best interests of shareholders.

Federal law has generally not been receptive to the idea of direct shareholder nomination of directors. Although the Commissionthrough Regulation $14 \mathrm{~A}^{264}$-has largely supplanted state regulation of shareholder voting, ${ }^{265}$ the federal proxy rules do not mandate or even permit shareholders direct access to the election process. Instead, Rule $14 \mathrm{a}-\mathrm{-}^{266}$ explicitly excludes director elections from the list of permissible subjects for which shareholders are afforded access to the issuer's proxy statement. In the late 1970s the Commission considered proposals that would have allowed shareholders to nominate director candidates directly, but issuer resistance to these proposals proved effective. $^{267}$ By 1990, the Commission had determined that shareholder proposals seeking to implement greater shareholder

263. See Jayne W. Barnard, Shareholder Access to the Proxy Revisited, 40 CATH. U. L. REV. 37, 54-62 (1990) (describing multiple types of proposals to permit direct shareholder nomination of directors); Martin Lipton \& Steven A. Rosenblum, A New System of Corporate Governance: The Quinquennial Election of Directors, 58 U. CHI. L. REV. 187, $224-52$ (1991) (advocating quinquennial election of directors coupled with the ability of large shareholders to nominate director candidates).

264. 17 C.F.R. $§ 240.14 a(2003)$.

265. See Jill E. Fisch, From Legitimacy to Logic: Reconstructing Proxy Regulation, 46 VAND. L. REV. 1129, 1192-93 (1993) (arguing that extensive federal regulation of shareholder voting through the proxy rules has discouraged development of state law).

266. 17 C.F.R. $\$ 240.14 a-8(I)(8)$.

267. See, e.g., Barnard, supra note 263, at 62-67 (describing the Commission's consideration and eventual abandonment of proposals to allow direct nomination of directors by shareholders). 
choice on an issuer-by-issuer basis were excludable from the issuer's proxy statement under Rule $14 a-8{ }^{268}$

Recently, however, in response to calls from institutional investors for greater director accountability in light of the widespread governance scandals, the Commission has taken a modest stand in favor of greater shareholder access to the nomination process. In the spring of 2003, the Commission directed the Division of Corporate Finance to examine the current proxy rules and "to formulate possible changes in the proxy rules and regulations and their interpretations regarding procedures for the election of corporate directors" in order to "improve corporate democracy." 69

In response to this directive, the Division of Corporate Finance solicited public views regarding shareholder access to the nomination process, ${ }^{270}$ and on July 15, 2003, the division published a staff report identifying five proposals for increasing shareholder involvement in the nomination and election of directors. ${ }^{271}$ The Commission subsequently issued a proposed rule that would afford shareholders direct access to the director nomination process. This rule, proposed on October 14, 2003 and entitled "Security Holder Direct Nominations, "272 would permit shareholders collectively owning five percent of the issuer's voting securities, under certain circumstances, to nominate a specified number of director candidates and have those candidates included in the issuer's proxy statement. ${ }^{273}$ Depending on

268. See, e.g., Unocal Corp., SEC No-Action Letter, 1990 SEC No-Act. LEXIS 183 (Feb. 6, 1990) (informing Unocal that the staff will not recommend action if Unocal excludes from its proxy statement a shareholder proposal that would permit any shareholder who owns or controls at least 125,000 shares to make a directoral nomination); Bank of Boston, SEC NoAction Letter, 1990 SEC No-Act. LEXIS 206 (Jan. 26, 1990) (proposal to permit any shareholder eligible to make a shareholder proposal to make a directoral nomination may be excluded from the proxy pursuant to Rule $14 \mathrm{a}-8(\mathrm{c})(8))$.

269. Press Release No. 2003-46, SEC, Commission to Review Current Proxy Rules and Regulations to Improve Corporate Democracy, (Apr. 14, 2003) at http://www.sec.gov/news/ press/2003-46.htm (on file with the Duke Law Journal).

270. Notice of Solicitation of Public Views Regarding Possible Changes to the Proxy Rules, Exchange Act Release No. 47,778, 68 Fed. Reg. 24,530 (May 7, 2003).

271. Staff Report: Review of the Proxy Process Regarding the Nomination and Election of Directors, Division of Corporation Finance, SEC, (July 15, 2003) at http://www.sec.gov/news/ studies/proxyrpt.htm (on file with the Duke Law Journal).

272. Security Holder Direct Nominations, Exchange Act Release No. 48,626, 2003 SEC LEXIS 2431 (Oct. 14, 2003).

273. Id. at $* 55-56$. 
the size of the issuer's board of directors, the permitted number of shareholder nominees could range from one to three. ${ }^{274}$

Importantly, the Commission's proposal is extremely limited. As noted, shareholders would only be permitted to nominate a small minority of the issuer's directors. More significantly, shareholder access to the proxy statement would require a triggering event. ${ }^{275}$ As currently proposed, the rule requires that, for shareholders to have proxy access, either shareholders must withhold at least thirty-five percent of the votes cast from at least one of management's nominees for director or shareholders owning at least one percent of the issuer's stock must submit a proposal seeking proxy access and that proposal must receive the approval of a majority of the shareholders. ${ }^{276}$ If either of these triggering events were to occur, then, in the following year, shareholders would have the right to nominate up to three director candidates.

There are two possible interpretations of the proposal. On the one hand, the proposed rule may reflect a shift in the Commission's long-term resistance to director accountability to shareholders. The Commission may have recognized the importance of director accountability in ensuring the effectiveness of its board-focused initiatives for governance reform. If so, the proposed rule can be understood as move away from cosmetic changes in board structure toward a meaningful attempt to address director passivity.

On the other hand, it would be a considerable overstatement to characterize the proposal, at least in its current form, as a meaningful effort to increase director accountability to shareholders. The proposal is an awkward procedural mechanism that affords a limited number of institutional investors the theoretical opportunity to nominate a tiny number of director candidates over the course of two election cycles. Due to the limited number of nominations available through the process, most directors will not face any realistic threat of

274. Id. at *88-91.

As proposed, a company would be required to include one security holder nominee if the total number of members of the board of directors is eight or fewer, two security holder nominees if the number of members of the board of directors is greater than eight and less than 20 and three security holder nominees if the number of members of the board of directors is 20 or more.

Id. at $* 89$.

275. Id. at *36-62.

276. Id. at $* 37-38$. The Commission noted that it was considering a third triggering eventthe refusal of the issuer to implement a shareholder proposal that had received approval by a majority of the shareholders. Id. at *50-56. 
a challenge. And, due to the two-year cycle mandated by the requirement of a triggering event, shareholders will not be able to move promptly to address problems in director attention or responsiveness. Because of the substantial threshold requirements, even institutional investors will face significant collective action problems in utilizing the process.

These limitations suggest that, despite the appearance of increased director accountability, the actual impact of the proposal will be extremely limited. Indeed, the structure of the proposal offers reason to question whether the political obstacles to achieving meaningful director accountability through Commission rulemaking can be overcome. Given that effective shareholder voting is primarily the product of federal law rather than state law, the scope of the proposed rule offers little promise that the Commission is likely to afford shareholders a meaningful role in the director selection process.

This concern highlights a certain irony in the Commission's focus on the structure of the board of directors and the independence of directors. Through its previous initiatives regarding audit committees, and now through the introduction of QLCCs, the Commission has sought to formulate rules that specify who is qualified to serve as a director and that delineate the appropriate scope of the director's role, rather than to develop procedures through which shareholders can identify and elect the best director candidates. ${ }^{277}$ In particular, the Commission's rules reflect its policy judgment about the most important components of the director's role. Seen in this light, the Commission's approach reflects less of an incursion upon traditional state corporate governance regulation than a degree of paternalisman expectation that it is necessary for the Commission to identify and mandate ideal board structure and director qualifications because shareholders either cannot or will not make appropriate choices.

\section{CONCLUSION}

QLCCs reflect the Commission's vision of the ideal corporate governance structure for issuers to address the risk of misconductan independent committee of specialist directors. By promulgating

277. Cf. Ronald J. Gilson \& Reinier H. Kraakman, Reinventing the Outside Director: An Agenda for Institutional Investors, 43 STAN. L. REV. 863, 883-92 (1991) (suggesting that a corps of professional outside directors will increase shareholder choice and avoid the incentive problems associated with existing outside directors). 
Rule 205, and by providing incentives for issuers to create QLCCs, the Commission highlighted the benefits of creating a QLCC without describing the associated costs. Those costs may be substantial. In particular, QLCCs are likely to increase the cost to issuers of obtaining and retaining high quality directors, increase the demands on scarce director time, and create informational segmentation that may interfere with board collegiality and board-management relations. Accordingly, it is necessary to consider more carefully whether the claimed benefits of the QLCC justify these costs. In particular, will the creation and use of QLCCs lead to more active director oversight of corporate decisionmaking and reduce the incidence of misconduct?

In considering this question, it is helpful to look to the analogous example of the audit committee. The Commission has pressured issuers, directly and indirectly, to create audit committees and to staff those committees with directors who meet increasingly detailed requirements as to their qualifications and independence. Nonetheless, the extent to which the audit committee operates effectively to monitor management remains an open question, with at least some recent evidence suggesting that audit committees have proven less effective than the Commission had hoped.

The analogy between QLCCs and audit committees suggests that a rule-based approach requiring specialized board committees and mandating standards of independence may, by itself, be insufficient to address a widespread problem of director passivity. In particular, under the existing system, directors seemingly lack sufficient incentives to pay close attention to the issuer's affairs. Rather, under current law, it may be more rational for directors to limit the extent of their investigation and to choose to rely on advisors. Accordingly, this Article considers various mechanisms for increasing director incentives to monitor, including increased liability exposure, modified director compensation, and increased shareholder participation in director selection.

We conclude that the Commission's focus on cosmetic standards of corporate governance without paying careful attention to director incentives should make issuers cautious about rushing either to embrace or to condemn QLCCs. In particular, attorneys advising clients regarding the creation of a QLCC should weigh carefully the costs and benefits of the QLCC to each client. More generally, issuers, regulators, and courts need to consider the ways in which the effectiveness of the Commission's approach is limited by director 
passivity. The Commission, moreover, would do well to evaluate the strength of its commitment to creating incentives for active monitoring, such as by enhancing director accountability to shareholders. At the same time, courts, particularly the Delaware judiciary, must consider the long-term impact of the move toward specialist directors and whether modifications to liability rules offer an attractive way to increase board monitoring. 